\title{
НИЗКАЯ НАПРЯЖЕННОСТЬ ГЕОМАГНИТНОГО ПОЛЯ НА РУБЕЖЕ ПЕРМИ И ТРИАСА ПО РЕЗУЛЬТАТАМ ИССЛЕДОВАНИЯ ТРАППОВ КУЗНЕЦКОГО ПРОГИБА
}

Елисеев А. А., Щербакова В. В., Метелкин Д. В., Михальцов Н. Э., Жидков Г. ., Абашев В. В., Рогов А. М.

\begin{abstract}
Аннотация
Получены первые сведения об абсолютной величине напряженности магнитного поля Земли на рубеже перми - триаса по базальтам Кузнецкого прогиба, которые рассматриваются в качестве одного из проявлений инициальной стадии траппового магматизма при формировании Сибирской крупной изверженной провинции. Хорошая сохранность информации о древнем магнитном поле Земли в изученных базальтах мальцевской свиты обусловлена наличием мелких одно- и псевдооднодоменных зерен первичномагматического титаномагнетита, «запечатанных» внутри силикатного матрикса. Полученные определения палеонапряженности по методике Телье-Коэ удовлетворяют общепринятым критериям достоверности и свидетельствуют, что интенсивность магнитного поля Земли на рубеже перми - триаса в момент формирования траппов в Кузнецком прогибе была ниже почти на порядок по сравнению с современной. При этом средние значения виртуального дипольного момента для нижней кожухтинской $(1.9 \pm 0.6) \times 10^{\wedge} 22 \mathrm{Am}^{\wedge} 2$ и средней власовской $(1.1 \pm 0.7) \times 10^{\wedge} 22 \mathrm{Aм}^{\wedge} 2$ частей мальцевской свиты хорошо сопоставляются с определениями палеонапряженнности геомагнитного поля во время формирования ивакинской свиты Норильского района Сибирской провинции, что подтверждает точность традиционных региональных корреляций.
\end{abstract}

\section{Ключевые слова:}

Палеонапряженность, метод Телье, низкое мезозойское поле, Кузнецкий прогиб, мальцевская свита, Сибирская трапповая провинция 


\title{
УДК 550.384.7 \\ НИЗКАЯ НАПРЯЖЕННОСТЬ ГЕОМАГНИТНОГО ПОЛЯ НА РУБЕЖЕ ПЕРМИ И ТРИАСА ПО РЕЗУЛЬТАТАМ ИССЛЕДОВАНИЯ ТРАППОВ КУЗНЕЦКОГО ПРОГИБА (ЮЖНАЯ СИБИРЬ)
}

\author{
А. А. Елисеев ${ }^{1,2 *}$, В. В. Щербакова ${ }^{3 * *}$, Д. В. Метелкин ${ }^{1,2}$, Н. Э. Михальцов ${ }^{1,2}$, Г. В. \\ Жидков ${ }^{3}$, В. В. Абашев ${ }^{1,2}$, А.М. Рогов ${ }^{4}$. \\ ${ }^{1}$ Новосибирский государственный университет, г. Новосибирск \\ ${ }^{2}$ Институт нефтегазовой геологии и геофизики им. А.А. Трофимука СО РАН, \\ г. Новосибирск \\ ${ }^{3}$ Геофизическая обсерватория “Борок”, филиал Института физики Земли \\ им. О.Ю. Шмидта РАН, п. Борок \\ ${ }^{4}$ Казанский (Приволжский) федеральный университет, Институт геологии и нефтегазовых \\ технологий, г. Казань \\ *E-mail: Eliseevaa@ipgg.sbras.ru \\ **E-mail: valia@borok.yar.ru
}

\begin{abstract}
АННОТАЦИЯ
Получены первые сведения об абсолютной величине напряженности магнитного поля Земли на рубеже перми - триаса по базальтам Кузнецкого прогиба, которые рассматриваются в качестве одного из проявлений инициальной стадии траппового магматизма при формировании Сибирской крупной изверженной провинции. Хорошая сохранность информации о древнем магнитном поле Земли в изученных базальтах мальцевской свиты обусловлена наличием мелких одно- и псевдооднодоменных зерен первичномагматического титаномагнетита, «запечатанных» внутри силикатного матрикса. Полученные определения палеонапряженности по методике Телье-Коэ удовлетворяют общепринятым критериям достоверности и свидетельствуют, что интенсивность магнитного поля Земли на рубеже перми - триаса в момент формирования траппов в Кузнецком прогибе была ниже почти на порядок по сравнению с современной. При этом средние значения виртуального дипольного момента для нижней кожухтинской (1.9 \pm $0.6) \times 10^{22} \mathrm{Am}^{2}$ и средней власовской $(1.1 \pm 0.7) \times 10^{22} \mathrm{Am}^{2}$ частей мальцевской свиты хорошо сопоставляются с определениями палеонапряженнности геомагнитного поля во время формирования ивакинской свиты Норильского района Сибирской провинции, что подтверждает точность традиционных региональных корреляций.
\end{abstract}


Ключевые слова: палеонапряженность, метод Телье, низкое мезозойское поле, Кузнецкий прогиб, мальцевская свита, Сибирская трапповая провинция.

\section{ВВЕДЕНИЕ}

Абсолютная величина магнитного поля Земли (напряженность), контролируется, прежде всего, процессами во внешнем жидком ядре и на его границе с мантией. Возникающий здесь тепловой поток отвечает не только за смену режимов работы геодинамо, генерирующего магнитное поле Земли, но и параметры мантийной конвекции, зарождение и отрыв плюмов [Добрецов, 2010, 2020; Добрецов и др., 2021]. Анализ современной базы данных по палеонапряженности ( $\left.\mathrm{B}_{\text {anc }}\right)$, размещенной на сайте http://earth.liv.ac.uk/pint/, свидетельствует о значительных вариациях этой характеристики геомагнитного поля в геологической истории. Причем просматривается возможная корреляция периодов снижения напряженности, а также частоты инверсий магнитного поля Земли, с интенсивностью мантийных плюмов - очевидного проявления глобальных изменений на границе ядра и перестройке в работе геодинамо [Larson, Olson, 1991; Добрецов, 1994; Щербаков, Сычева, 2006; Диденко, 2011; Olson, Amit, 2015; Добрецов и др., 2021]. В частности, предполагается, что рубеж перми и триаса, отвечающий формированию крупнейшей изверженной провинции (LIP) на территории Сибири, соответствует эпизоду резкого снижения напряженности, которая по мнению ряда авторов ознаменовала начало эпохи низкого мезозойского поля (Mesozoic Dipole Low - MDL), длившегося вплоть до мелового периода [Prevot et al., 1990]. Главный минимум приходится на инициальную стадию формирования Сибирской LIP [Солодовников, 1994; Heunemann et al., 2004; Щербакова и др., 2005, 2013, 2015; Anwar et al., 2016], которая по времени совпадает с инверсией, записанной в базальтах ивакинской свиты Норильского, хардакской свиты Маймеча-Котуйского, сырадасайской свиты Таймырского районов, где получено максимально большое количество палеомагнитных определений [Lind et al., 1994; Gurevitch et al., 1995, 2004; Kravchinsky et al., 2005; Pavlov et al., 2007; Павлов и др., 2011; Веселовский и др., 2012; Михальцов и др., 2012; Фетисова и др., 2014; Latyshev et al., 2018; Латышев и др., 2019].

Однако значительная часть существующих мировых данных о палеонапряженности не поддерживают гипотезу MDL [Selkin, Tauxe, 2000; Tarduno et al., 2001, 2006; Goguitchaichvili et al., 2002]. В частности, значения палеонапряженности по результатам изучении пермо-триасовых силлов на востоке Сибирской LIP соответствуют величине виртуального дипольного магнитного момента $(\mathrm{VDM}) \sim 6 \times 10^{22} \mathrm{Am}^{2}$, лишь немного ниже современного $\sim 8 \times 10^{22} \mathrm{Am}^{2}$ [Blanco et al., 2012]. 
Ярким проявлением плюмового магматизма, соответствующего инициальной стадии формирования Сибирской LIP и способного пролить свет на проблему MDL, являются траппы Кузнецкого прогиба на юге Сибири. Полученные петрохимические данные, геохронологические оценки [Федосеев и др., 2005; Reichow et al., 2009; Буслов и др., 2010; Наставко и др., 2012] и первые палеомагнитные данные [Казанский и др., 2005] позволили обосновать корреляцию траппов Кузбасса в составе мальцевской свиты с ивакинским событием Норильского района Сибирской LIP на рубеже перми - триаса, около 250 млн лет назад. Таким образом, главной целью настоящего исследования было обоснование абсолютной величины геомагнитного поля, записанной в базальтах Кузнецкого магматического ареала.

\section{КРАТКАЯ ГЕОЛОГО-ПАЛЕОМАГНИТНАЯ ХАРАКТЕРИСТИКА ОБЪЕКТА ИССЛЕДОВАНИЯ}

Кузнецкий прогиб расположен в юго-западном обрамлении Сибирского кратона между горных поднятий Салаирского кряжа и Кузнецкого Алатау (рис. 1). Трапповый комплекс слагает несколько небольших ареалов, главный из которых на северо-востоке прогиба выполняет Бунгарапскую синклиналь. В составе комплекса, кроме характерных для LIP вулканических и субвулканических тел основного состава, широко представлены туфогенно-осадочные и терригенные породы континентального генезиса [Кутолин, 1963; Буслов и др., 2010]. Наиболее представительные для изучения палеонапряженности разрезы слагают северное крыло Бунгарапской синклинали (рис. 2). Здесь в пределах Салтымаковского хребта, преимущественно в береговых обнажениях р. Томь, распространены базальтовые, андезибазальтовые покровы, объединяемые вместе с туфогенно-осадочными пачками в составе мальцевской свиты. Среди других районов Кузнецкого прогиба этот ареал распространения мальцевской свиты отличается исключительным преобладанием вулканических пород и максимальной мощностью пластовых тел (более 100 м) [Кутолин, 1963; Буслов и др., 2010]. Комплекс геологогеофизических данных позволяет реконструировать здесь крупную палеовулканическую постройку, центр которой отражен положительной гравитационной аномалией [Лавренов и др., 2008 а,б]. По данным бурения разрез включает не менее семи покров [Наставко и др., 2012], границы которых в естественных обнажениях чаще всего не вскрыты. Нижние покровы представлены преимущественно базальтами и трахибазальтами, а верхние андезибазальтами и трахиандезибазальтами. Вулканиты имеют выдержанный минералогопетрографический состав, темно-серый до черного цвет, чаще всего порфировую, реже афировую или пойкилоофитовую структуру, миндалекаменную или массивную текстуру. 
Базальты сложены оливином (10 - 15\%), плагиоклазом (60\%), клинопироксеном (0 - 5\%), стеклом (20\%). Минералогический состав андезибазальтов включает оливин (1 5\%), плагиоклаз (25 - 50\%), клинопироксен (5 - 20\%), стекло (30 - 60\%). Среди акцессорных минералов всегда преобладает титаномагнетит $(1-3 \%)$, также встречается ильменит и апатит, единичные зерна ильменита, пирита, пирротина, халькопирита [Наставко и др., 2012].

Значительное петрохимическое сходство вулканитов мальцевской свиты с нижним стратиграфическим уровнем Сибирской LIP, главным образом Норильского района, отражено во многих работах [Крук и др., 1999; Буслов и др., 2010; Наставко и др., 2012]. Они имеют сходное изотопное отношение ${ }^{87} \mathrm{Sr} /{ }^{86} \mathrm{Sr}$ от 0.7043 до 0.7056 [Reichow et al., 2010] и образованы из обедненного мантийного источника, на что указывает положительное значение $\varepsilon N d$ от +2.3 до +3.1 [Крук и др., 1999]. Наиболее значительными доводами в пользу корреляции траппов Кузбасса с инициальной (ивакинской) стадией магматизма Норильского района на рубеже перми - триаса являются ${ }^{40} \mathrm{Ar} /{ }^{39} \mathrm{Ar}$ данные [Федосеев и др., 2005; Reichow et al., 2009; Буслов и др., 2010; Наставко и др., 2012] и палеомагнитные сопоставления [Казанский и др., 2005]. Согласно последним, намагниченность всего разреза мальцевской свиты обладает исключительно обратной полярностью и соответствует магнитозоне $\mathrm{R}_{3} \mathrm{P}$ гиперзоны Иллавара по шкале [Молостовский, Храмов, 1984; Молостовский и др., 2007]. К концу этого ортохрона традиционно привязывалась граница перми - триаса [Hongfu et al., 2001], которая в разрезе траппов Норильского района помещалась между ивакинской и вышележащей сыверминской свитами [Lind et al., 1994]. Согласно данным изотопной геохронологии возраст этой границы соответствует 250 млн лет [Reichow et al., 2009]. В международной магнитостратиграфической шкале [Steiner, 2006] граница перми - триаса проводится ниже этой магнитозоны и ее возраст отвечает 251.99 млн лет [Gradstein et al., 2020]. Далее, не вдаваясь в проблемы стратиграфии, мы принимаем возраст формирования вулканитов мальцевской свиты и фиксации намагниченности в них - 250 млн лет. Первичный генезис намагниченности обоснован тестами складки и отжига, а также результатами магнитоминералогических исследований [Казанский и др., 2005]. В том числе показано, что главным носителем намагниченности является титаномагнетит. При этом основная часть естественной остаточной намагниченности (NRM) приходится на магнитную фазу с деблокирующими температурами $\left(\mathrm{T}_{\text {дб}}\right) 300-350{ }^{\circ} \mathrm{C}$, что приблизительно соответствует содержанию 40\% ульвошпинелевого минала [Nishitani, Kono, 1983]. Вторая наиболее часто встречаемая фаза с $\mathrm{T}_{\text {дб }} 500-580^{\circ} \mathrm{C}$ является продуктом его гетерофазного окисления. Однако сам процесс распада твердых растворов происходил практически сразу после 
остывания магматических тел, и фиксируемая характеристическая компонента намагниченности исходного и обогащенного железом титаномагнетитов не различаются [Казанский и др., 2005]. В пользу этого говорят результаты численного моделирования динамики остывания субвулканических интрузий (силлов) Норильского района [Метелкин и др., 2019].

Непосредственным объектом настоящего исследования, ориентированного на оценку палеонапряженности вблизи границы перми - триаса, стали базальты, опробованные на участке от устья руч. Бугас до руч. Дулепова (участок IV в статье [Казанский и др., 2005]) (рис 2). Вслед за В.А. Кутолиным мы рассматриваем разрез мальцевской свиты этого участка в составе нижней - кожухтинской толщи (рис. 2, сайты $a d-1, a d-2$ и $a d-5)$, представленной, преимущественно, базальтами, и средней - власовской толщи (сайт ad-3), где преобладают андезибазальтовые покровы [Кутолин, 1963]. Обнажения самой верхней - коврижкинской толщи расположены выше по течению р. Томь и в этой работе не рассматриваются.

\section{МЕТОДЫ ИССЛЕДОВАНИЯ, АППАРАТУРА, МЕТОДИКИ}

Работа выполнена с использованием аппаратуры лаборатории геодинамики и палеомагнетизма Центральной и Восточной Арктики НГУ, лаборатории геодинамики и палеомагнетизма ИНГГ СО РАН, палеомагнитной лаборатории Геофизической обсерватории «Борок» ИФЗ РАН и Междисциплинарного центра "Аналитическая микроскопия" КФУ.

Наиболее надежным методом оценки палеонапряженности является процедура, основанная на выполнении законов Телье независимости и аддитивности парциальных термоостаточных намагниченностей (pTRM) [Thellier, Thellier, 1959]. Эти законы выполняются для однодоменных (ОД) и мелких псевдооднодоменных (ПОД) магнитных зерен и нарушаются для крупных многодоменных (МД) частиц [Shcherbakova et al., 2000]. Наличие в породе МД зерен как носителей pTRM вносит заметную ошибку в оценку $\mathrm{B}_{\mathrm{anc}}$ [Shcherbakova et al., 2000]. Поэтому в экспериментах по определению $\mathrm{B}_{\text {anc, помимо }}$ доказательств первичности, термооостаточной природы и термостабильности естественной остаточной намагниченности (NRM), необходимы оценки доменной структуры (ДС) носителей ее характеристической компоненты (ChRM). В этой связи при изучении коллекции, кроме экспериментов по определению $\mathrm{B}_{\mathrm{anc}}$, нами выполнен комплекс измерений различных магнитных и термомагнитных параметров, описанных ниже.

Термостабильность магнитных минералов оценивалась по серии кривых намагниченности насыщения $\mathrm{M}_{\mathrm{si}}(\mathrm{T})$ (рис. За), записанных при последовательных нагревах 
от 100 до $700{ }^{\circ} \mathrm{C}$ с шагом $100^{\circ} \mathrm{C}$, и по кривым магнитной восприимчивости к(Т) (рис. Зб), снятых при двух последовательных нагревах: до $~ 360^{\circ} \mathrm{C}$, что соответствует температуре Кюри $\left(\mathrm{T}_{\mathrm{c}}\right)$ основного носителя намагниченности, и до $600^{\circ} \mathrm{C}$ - немного выше $\mathrm{T}_{\mathrm{c}}$ второго по встречаемости в исследуемых породах магнитного минерала [Казанский и др., 2005]. $\mathrm{T}_{\mathrm{c}}$ определялась по экстремуму первой производной $\mathrm{M}_{\mathrm{s}}(\mathrm{T})$ [Fabian et al., 2013]. Термокривые $\mathrm{M}_{\text {si }}(\mathrm{T})$ снимались на магнитных весах конструкции Ю.К. Виноградова во внешнем магнитном поле 450 мТл, измерения к(T) выполнялись на приборе «AGICO MFK-1A» (Чехия).

ДС ферримагнитных зерен оценивалась по диаграмме Дэя в модификации Д. Данлопа [Day, 1977; Dunlop, 2002] и термомагнитному критерию [Большаков, Щербакова, 1979; Shcherbakova et al., 2000]. На коэрцитиметре конструкции П.Г. Ясонова при комнатной температуре $\mathrm{T}_{0}$ в полях до 0.7 Тл определялись гистерезисные параметры: намагниченность насыщения $\mathrm{M}_{\mathrm{s}}$, коэрцитивная сила $\mathrm{B}_{\mathrm{c}}$ и их аналоги остаточной намагниченности - $\mathrm{M}_{\mathrm{rs}}$ и $\mathrm{B}_{\mathrm{cr}}$. Для построения диаграммы рассчитывались отношения $\mathrm{M}_{\mathrm{rs}} / \mathrm{M}_{\mathrm{s}}, \mathrm{B}_{\mathrm{cr}} / \mathrm{B}_{\mathrm{c}}$. Используемые параметры отражают магнитные характеристики всего присутствующего в породе ферримагнитного материала, в том числе и крупных многодоменных зерен, но не дают информацию о вкладе МД зерен в TRM, что существенно для определения $\mathrm{B}_{\mathrm{anc}}$ по методике Телье. Для ответа на этот вопрос используется термомагнитный критерий оценки ДС магнитных зерен по поведению их pTRM. pTRM, созданная в температурном интервале $\left(\mathrm{T}_{1}, \mathrm{~T}_{2}\right.$, где $\left.\mathrm{T}_{1}>\mathrm{T}_{2}\right)$, при последующем нагреве до $\mathrm{T}_{1}$ и охлаждения до $\mathrm{T}_{0}$ полностью разрушается у ОД зерен (остаток при $\mathrm{T}_{0}-$ «Хвост» < 5\%), у ПОД зерен 5\% < «Хвост» < 15\% и у МД зерен «хвост»> 15\% [Shcherbakova et al., 2000]. В наших экспериментах дубли образцов прогревались до точки Кюри, и при охлаждении в нулевом поле при $250^{\circ} \mathrm{C}$ включалось лабораторное поле, т.е. создавалась pTRM(250, $\left.\mathrm{T}_{0}\right)$. Далее образец в нулевом поле грелся до $250^{\circ} \mathrm{C}$, охлаждался до $\mathrm{T}_{0}$, и делался замер.

Рентгенодифрактометрические исследования отсепарированной магнитной фракции осуществлялись на порошковом дифрактометре «STOE STADI-MP» (Германия) с монохроматизированным $\mathrm{CoK}_{\alpha 1}$-излучением. С целью детального изучения структуры и состава магнитной фракции также были выполнены исследования на сканирующем электронном микроскопе «Carl Zeiss MERLIN» (Германия).

Для определения $\mathrm{B}_{\mathrm{anc}}$ в качестве базовой процедуры использовался метод Телье в модификации Коэ [Thellier, Thellier, 1959; Coе, 1967]. Парные нагревы с шагом 25, 30 C в немагнитной печи «MMTDSC» (Великобритания) выполнялись в бескислородной среде (азот), первый шаг (нагрев - охлаждение) - в нулевом поле, второй - в лабораторном поле 
$\mathrm{B}_{\text {lab }}=50$ мкТл. Для контроля возможных минералогических изменений через каждые 2 температурных шага выполнялись дополнительные «возвратные» нагревы до более низких температур с созданием рTRM (процедура “check-point” [Prevot et al., 1985]). Измерения остаточной намагниченности проводились с использованием «2G Enterprises SQUID Magnetometer» (США). В экспериментах использованы 43 образца - кубика с гранью 2 см. Нагревы проводились для партий в 12 -17 образцов. Чтобы контролировать идентичность условий проведения эксперимента, дубли нескольких образцов включались в разные партии. Всего выполнялось от 11 до 17 двойных нагревов и от 5 до 8 возвратных нагревов (check-points). Для сравнения и контроля полученных значений $\mathrm{B}_{\mathrm{anc}}$ на группе из 17 образцов-дублей выполнено определение палеонапряженности с использованием трехкомпонентного вибромагнитометра конструкции Ю.К. Виноградова «Орион» (Россия). Измерения выполнялись в автоматическом режиме при фиксированном положении в держателе прибора неориентированного кубика с гранью 1 см. Использовалось лабораторное поле $\mathrm{B}_{\mathrm{lab}}=10$ или 20 мкТл.

Для оценки величины $\mathrm{B}_{\text {anc }}$ по результатам измерений для каждого образца строились диаграммы Араи-Нагата (АН) (рис. Зв) и Зийдервельда в координатах образца (рис. Зг). При анализе оценивалось качество каждого определения $\mathrm{B}_{\text {anc }}$ и отбраковывались те измерения, которые не согласовывались со списком современных критериев достоверности, предъявляемым к данным по $\mathrm{B}_{\text {anc }}$ [Shcherbakova et al., 2020]. K дальнейшим расчетам VDM принимались только те определения $\mathrm{B}_{\mathrm{anc}}$, которые удовлетворяли следующим позициям: 1) линейный отрезок (fit) АН-диаграммы в температурном fitинтервале $\left(\mathrm{T}_{1}-\mathrm{T}_{2}\right)$ должен содержать не меньше 4 репрезентативных точек, 2) доля NRM, теряемой в fit-интервале $\left(\mathrm{T}_{1}-\mathrm{T}_{2}\right)$ (параметр $\mathrm{F}$ ), составляет не менее $20 \%$ от полного значения NRM, 3) смещение точек «pTRM check» по отношению к первоначальным позициям PTRM, нормализованное на полную величину NRM, не превышает 5\%, 4) параметры DRAT и CDRAT должны быть в пределах $\pm 15 \%$ (DRAT - максимальное отклонение контрольных точек, разделенное на TRM(T $\left.\mathrm{T}_{1}-\mathrm{T}_{2}\right)$ в процентах [Selkin, 2000]; CDRAT - сумма отклонений контрольных точек разделенная на $\operatorname{TRM}\left(\mathrm{T}_{1}, \mathrm{~T}_{2}\right)$ в процентах [Laj et al., 2004]); 5) на диаграммах Зийдервельда в интервале ( $\left.\mathrm{T}_{1}-\mathrm{T}_{2}\right)$ вектор NRM не меняет своего направления и, в пределах ошибки определения, соответствует известному направлению пермо-триасовой компоненты $\left(D_{s}=227,1, I_{s}=-64,3, \alpha_{95}=2,8\right)$ по данным [Казанский и др., 2005]; 6) для fit-интервала $\left(\mathrm{T}_{1}-\mathrm{T}_{2}\right)$ АН-диаграммы рассчитываются также факторы: GAP (g) - равномерность распределения точек на диаграмме по оси ординат, b средневзвешенный тангенс угла наклона кривой, $\mathrm{f}$ - доля NRM, которая приходится на интервал $\left(\mathrm{T}_{1}, \mathrm{~T}_{2}\right), \sigma_{\mathrm{b}}$ - средне квадратичная погрешность среднего арифметического b. По 
формуле $\mathrm{Q}=\mathrm{gbf} / \sigma_{\mathrm{b}}$ рассчитывается интегральная оценка качества результата, заслуживающими доверия признаются те, для которых $\mathrm{Q} \geq 5$ [Coe et al., 1978]. Дополнительными параметрами качества служат стандартная ошибка наклона линии аппроксимации beta $\leq 0.1$; FRAC - аналог F, позволяющий более корректно учитывать вогнутые участки АН-диаграмм [Shaar, Tauxe, 2013]; d(CK) - максимальное отклонение контрольных точек (pTRM-checks), разделенное на максимальное TRM в процентах [Leonhardt et al., 2000].

Для верификации значений $\mathrm{B}_{\mathrm{anc}}$, полученных методом Телье-Коэ, на дублях 11 образцов выполнено определение $\mathrm{B}_{\text {anc }}$ методом Вилсона [Wilson, 1961]. Этот способ заключается в оценке подобия кривых непрерывного терморазмагничивания двух намагниченностей - природной $\mathrm{NRM}\left(\mathrm{T}, \mathrm{B}_{\text {anc }}\right)$ и лабораторной $\mathrm{TRM}\left(\mathrm{T}, \mathrm{B}_{\mathrm{lab}}\right)$, созданной при охлаждении образца в лабораторном поле $\mathrm{B}_{\mathrm{lab}}$. Для этого полученный непрерывный ряд значений TRM(T) умножается на подобранный коэффициент к* так, чтобы новая кривая TRM*(T) была максимально близка к NRM(T). После чего выделяется температурный интервал $\left(\mathrm{T}_{1}^{*}, \mathrm{~T}_{2}\right),\left(\mathrm{T}_{1}{ }_{1}>\mathrm{T}^{*}\right)$, где обе кривые совпадают, и по нему делается экспрессоценка величины поля: $\mathrm{B}_{\text {anc }}=\mathrm{K}^{*} \mathrm{~B}_{\text {lab }}$ (рис. Зд). Близость значений $\mathrm{B}_{\text {anc }}$ и $\mathrm{B}_{\text {anc, }}$, полученных для одного образца двумя разными методами - Телье и Вилсона, повышает достоверность оценки величины палеонапряженности. А сам факт подобия кривых NRM(T) и TRM*(T) служит существенным доводом в пользу того, что NRM является термоостаточной по своей природе. Дополнительный плюс этого метода состоит в том, что он не зависит от доменной структуры исследуемых образцов [Maxworthy, 2010]. Тем не менее, метод Вилсона здесь применен только в качестве контрольного, а для расчета VDM

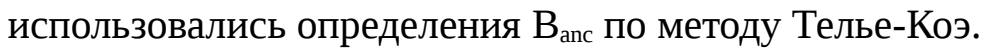

\section{ТЕРМОСТАБИЛЬНОСТЬ ОБРАЗЦОВ, ИХ ТЕМПЕРАТУРЫ КЮРИ И ДОМЕННАЯ}

\section{СТРУКТУРА}

Из анализа кривых $\mathrm{M}_{\mathrm{si}}(\mathrm{T})$ (рис. За) и к(T) (рис. 3б) следует, что исследованные образцы стабильны при нагревах вплоть до 350 - $400{ }^{\circ} \mathrm{C}$. Кривые к(T), записанные в процессе первого цикла (нагрев до $360{ }^{\circ} \mathrm{C}$ - охлаждение до $\mathrm{T}_{0}$ ), мало различаются, что свидетельствует об отсутствии значимых минералогических преобразований во время эксперимента. Рост магнитной восприимчивости при первом нагреве с максимумом на кривой к(Т) вблизи $250{ }^{\circ} \mathrm{C}$ может быть связан с эффектом Гопкинсона, возникающим за счет резкого снижения магнитной анизотропии МД частиц или перехода ОД зерен в суперпарамагнитное состояние при температурах, близких к $\mathrm{T}_{\mathrm{c}}$ [Нагата, 1965]. Нагревы до 
более высоких температур вызывают значительные минералогические изменения состава ферримагнитных зерен, что проявляется в несовпадении термомагнитных кривых, записанных при нагреве и охлаждении, а также при последующем нагреве образцов. У некоторых образцов при нагреве выше 450 - $500{ }^{\circ} \mathrm{C}$ на кривой к(Т) виден явно выраженный второй максимум (рис. 3б). В том же температурном интервале на кривых $\mathrm{M}_{\mathrm{si}}(\mathrm{T})$ наблюдается рост значений $\mathrm{M}_{\mathrm{s}}$ (рис. За). Этот факт свидетельствует о присутствии новообразованной магнитной фазы, предположительно высокожелезистого титаномагнетита.

Температуры Кюри исходного титаномагнетита, определенные по кривым $\mathrm{M}_{\mathrm{si}}(\mathrm{T})$ и к(Т), для изученных базальтов кожухтинской толщи составляют $~ 320^{\circ} \mathrm{C}$, а власовской толщи варьируют от 320 до $400^{\circ} \mathrm{C}$ (рис. За, б).

Обратим внимание на особенности вычисления гистерезисных параметров изучаемых образцов путем аппроксимации их петель гистерезиса. Стандартный расчет предполагает, что в достаточно высоких полях В происходит насыщение ферримагнитной составляющей, и далее индуктивная намагниченность $\mathrm{M}_{\mathrm{i}}(\mathrm{B})$ растет пропорционально полю за счет парамагнитной компоненты, так что кривая намагничивания поднимается вверх четко по прямой линии. Исходя из этого, обычная процедура выделения парамагнитной составляющей для нахождения $\mathrm{M}_{\mathrm{s}}$ заключается в том, что график индуктивной намагниченности $\mathrm{M}_{\mathrm{i}}(\mathrm{B})$ при высоких полях представляется уравнением прямой линии $\mathrm{M}_{\mathrm{i}}(\mathrm{B})=\mathrm{aB}+\mathrm{M}_{\mathrm{s}}$, где $\mathrm{aB}$ - линейный член, соответствующий парамагнитной части, a $\mathrm{M}_{\mathrm{s}}$ есть намагниченность насыщения ферримагнитной составляющей. Пересечение этой прямой линии с осью ординат и дает значение $\mathrm{M}_{\mathrm{s}}$. Известно, что для одноосных зерен, оси которых равномерно распределены по сфере, отношение $\mathrm{M}_{\mathrm{rs}} / \mathrm{M}_{\mathrm{s}}$ не превышает 0.5 [Нагата, 1965]. В нашем случае расчет по этой методике привел к отношениям $\mathrm{M}_{\mathrm{rs}} / \mathrm{M}_{\mathrm{s}} \approx 0.6-0.8$. Вообще говоря, столь высокие значения $\mathrm{M}_{\mathrm{rs}} / \mathrm{M}_{\mathrm{s}}$ могут наблюдаться при сильной анизотропии, либо в ансамбле изометричных магнитных зерен, характеризующихся многоосной анизотропией. Ни то, ни другое не соответствует изучаемым образцам; они обладают слабой анизотропией: средняя восприимчивость $\mathrm{K}_{\mathrm{m}}=$ $2.4 \pm 1.9 \times 10^{-3}$, степень анизотропии $\mathrm{P}=1.02 \pm 0.02$, форма анизотропии $\mathrm{T}=0.2 \pm 0.4$. С другой стороны, такие высокие значения $\mathrm{M}_{\mathrm{rs}} / \mathrm{M}_{\mathrm{s}}$ могут быть артефактом, связанным с тем, что магнитожесткая компонента не насыщается в приложенных полях [Fabian et al., 2006], что выражается в наличии определенной выпуклости на графике $\mathrm{M}_{\mathrm{i}}(\mathrm{B})$ в высоких приложенных полях В (рис. 4а, б). В этой ситуации пересечение аппроксимирующей прямой линии с осью ординат дает заниженные значения $\mathrm{M}_{\mathrm{s}}$, соответственно, завышенные значения $\mathrm{M}_{\mathrm{r}} / \mathrm{M}_{\mathrm{s}}$ В этом случае для учета кривизны формы восходящей петли 
гистерезиса при высоких В и корректного расчета гистерезисных параметров в правую часть уравнения $\mathrm{M}_{\mathrm{i}}(\mathrm{B})=\mathrm{aB}+\mathrm{M}_{\mathrm{s}}$ следует ввести дополнительный член -b/B, моделирующий приближение к насыщению [Fabian et al., 2006]. Конкретные величины параметров a, b и $\mathrm{M}_{\mathrm{s}}$ рассчитываются методом наименьших квадратов путем уменьшения невязки теоретических и эмпирических кривых (рис. 4б). Для наглядного представления различия квадратичного и линейного приближений рассчитан квадрат разницы экспериментальной и аппроксимационных кривых на примере одного образца (рис. 4в). Применение такой процедуры к исследуемым образцам привело к корректировке величин $\mathrm{M}_{\mathrm{s}}$ (их увеличению) и, соответственно, к уменьшению отношений $\mathrm{M}_{\mathrm{rs}} / \mathrm{M}_{\mathrm{s}}$ до приемлемых значений $<0.5$.

Точки на диаграмме Дэя-Данлопа (рис. 4д) расположены вблизи участка расчетной кривой, соответствующего псевдооднодоменным зернам субмикронного размера, либо смеси магнитных частиц различного размера, содержащей 30-40\% многодоменных зерен среди преобладающих однодоменных [Dunlop, Ozdemir, 1997; Dunlop, 2002]. При этом точки смещены влево от расчетных кривых, что также может быть результатом недонасыщения магнитожестких зерен, приводящего к искажению получаемых величин $\mathrm{B}_{\mathrm{cr}}$ и $\mathrm{B}_{\mathrm{c}}$ и их отношения.

Оценка ДС по термомагнитному критерию была выполнена на породах кожухтинской толщи, у которых при нагреве до $\mathrm{T}_{\mathrm{c}}$ полное разрушение NRM происходит без видимых минералогических изменений. В качестве примера на рисунке 4 г показан график $\operatorname{pTRM}\left(250, \mathrm{~T}_{0}\right)=\mathrm{f}(\mathrm{T})$ образца кожухтинской толщи. Видно, что при нагреве до $250^{\circ} \mathrm{C}$ созданная $\mathrm{pTRM}\left(250, \mathrm{~T}_{0}\right)$ полностью разрушилась, и после охлаждении до $\mathrm{T}_{0}$ остаточная намагниченность близка к нулю. Согласно термомагнитному критерию, отсутствие «хвоста» означает, что носителями рTRM являются ОД зерна.

Таким образом, оба метода оценки ДС указывают на то, что носителями намагниченности исследуемых образцов являются ОД и/или малые ПОД зерна, что определяет возможность их использования для измерения палеонапряженности.

\section{ЭЛЕКТРОННАЯ МИКРОСКОПИЯ И РЕНТГЕНОСТРУКТУРНЫЙ АНАЛИЗ}

На снимке при увеличении 100 мкм отчетливо видны только породообразующие минералы, в том числе крупные зерна плагиоклаза и клинопироксена (рис. 5а). На увеличенном в 10 раз снимке зерна титаномагнетита идентифицируются как небольшие светлые точки размером около 0.2 - 0.7 мкм (рис. 5б), что подтверждает наши выводы о их преобладающем ОД и ПОД состоянии. Также отмечаются характерные структуры 
скелетной формы (рис. 5в), что указывает на экстремально быстрое охлаждение и кристаллизацию, способствующие хорошей сохранности палеомагнитной записи, отвечающей моменту извержений. Содержание массовой доли титана в этих зернах определить не удается, поскольку размер зонда заметно больше ( $1-2$ мкм) и захватывает область вмещающей массы (рис. 5г).

Согласно результатам рентгеноструктурного анализа, шпинельная фракция представлена минералом с величиной постоянной решетки $\mathrm{a}_{0}=0.845-0.846$ нм, что соответствует титаномагнетиту с ульвошпинеливым миналом 40 - 50\% и, соответственно, теоретической $\mathrm{T}_{\mathrm{c}} \sim 300^{\circ} \mathrm{C}$ [Nishitani, Kono, 1983]. Наблюдаемые $\mathrm{T}_{\mathrm{c}}$ в базальтах кожухтинской толщи лишь незначительно превышают это значение, а иногда встречаемые по кривым $\mathrm{M}_{\mathrm{si}}(\mathrm{T})$ и к(T) высокие $\mathrm{T}_{\mathrm{c}}$ до $450^{\circ} \mathrm{C}$ в андезибальтах власовской толщи следует связать с незначительным окислением исходных титаномагнетитов во время остывания, практически сразу после излияний [Казанский и др., 2005]. Мы полагаем, что непосредственно во время остывания лавовых потоков, зерна титаномагнетита выпали в силикатную матрицу и оказались запечатанными в ней. Именно поэтому магнитную фракцию в чистом виде, как правило, выделить не удается, и соответствующие линии на дифрактограммах заметно искажены интенсивными рефлексами силикатов.

Подобные структуры распада титаномагнетита внутри силикатной матрицы неоднократно наблюдались [Tarduno et al., 2001, 2006; Щербакова и др., 2017]. Показано, что кристаллизация титаномагнетита при этом происходит при температурах, превышающих его $\mathrm{T}_{\mathrm{c}}$, соответственно фиксируемая намагниченность гарантированно имеет термоостаточную природу, а магнитные зерна оказываются надежно запечатаны и защищены от последующих химических и структурных изменений, обеспечивая идеальную сохранность палеомагнитной записи [Tarduno et al., 2006].

\section{РЕЗУЛЬТАТЫ ОПРЕДЕЛЕНИЯ ПАЛЕОНАПРЯЖЕННОСТИ}

Всего в экспериментах по определению палеонапряженности методом Телье было задействовано 60 образцов, из них 43 образца изучено с использованием отдельно стоящей большой немагнитной печи и криогенного магнитометра и 17 образцов с использованием трехкомпонентного вибромагнитометра. Для большинства исследованных образцов диаграммы Араи-Нагата и Зийдервильда имеют общие характерные черты (рис. Зв). Как правило, на них прослеживаются две компоненты. Первая - вязкая компонента, обусловленная действием современного магнитного поля, разрушается при нагреве до температур $100-125^{\circ} \mathrm{C}$. Вторая - характеристическая (ChRM) компонента, разрушается в интервале 125 - 300․ На АН-диаграммах позиции контрольных точек (check-points) 
совпадают или близки к первичным точкам, что указывает на отсутствие химических изменений в процессе нагревов, и также наблюдается четкий прямолинейный участок (fitинтервал), по которому делалась оценка $\mathrm{B}_{\mathrm{anc}}$ и рассчитывались соответствующие параметры качества (см. выше). Подавляющее большинство определений $\mathrm{B}_{\text {anc }}$ (34 из 41), полученные по базальтам кожухтинской толщи, отвечают необходимым критериям (табл. 1). Андезибальты власовской толщи несколько менее стабильны к нагревам, что отражается в заметных сдвигах контрольных точек от линии аппроксимации. Тем не менее

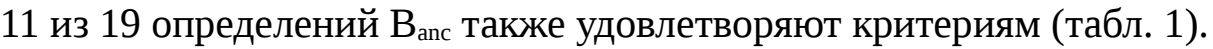

Определения, выполненные с использованием криогенного магнитометра и вибромагнитометра, как правило, дают близкие значения $\mathrm{B}_{\mathrm{anc}}$. При этом параметры качества несколько выше для данных, полученных на вибромагнитометре. Этот факт довольно просто объясняется условиями проведения эксперимента, поскольку в первом случае необходимо перемещение образцов от печи к магнитометру. Тем не менее, общее сходство значений $\mathrm{B}_{\mathrm{anc}}$, полученных с использованием различной аппаратуры, может быть косвенным доводом в пользу их достоверности. Об этом же свидетельствуют результаты экспериментов по методу Вилсона. Соответствующие графики демонстрируют подобие кривых NRM и TRM* (рис. Зд), а полученные значения B* anc не отличаются от $\mathrm{B}_{\text {anc }}$ (табл. 1).

Таким образом, всего удалось получить 45 валидных определений $\mathrm{B}_{\text {anc. }}$ В расчете среднего по сайту участвует не менее 7 определений (табл. 2). Для расчета VDM использована стандартная формула:

$$
V D M=0.5 \times B_{a n c} r^{3} \sqrt{1+3 \sin ^{2} I} \times 10^{7},
$$

где $\mathrm{B}_{\mathrm{anc}}$ - среднее по сайту значение палеонапряженности, $\mathrm{r}$ - радиус Земли, I - значение магнитного наклонения, здесь мы в каждом случае использовали значение $64.2^{\circ}$, которое получено в результате осреднения заметно большего массива палеомагнитных данных по территории Кузнецкого прогиба [Казанский и др., 2005].

\section{ОБСУЖДЕНИЕ РЕЗУЛЬТАТОВ}

По нашим данным на рубеже пермь - триас величина геомагнитного поля была как минимум в 3 раза ниже современной. Рассчитанные средние по сайтам значения VDM, с учетом стандартного отклонения (табл. 2), изменяются в пределах $(0.5-2.5) \times \cdot 10^{22}$ Ам $^{2}$ Такая оценка подтверждает и хорошо согласуется с имеющимися определениями $\mathrm{B}_{\mathrm{anc}}$ по одновозрастным траппам Норильского и Маймеча-Котуйского ареалов Сибирской LIP 
[Большаков, Солодовников, 1976; Солодовников, 1994; Heunemann et al, 2004; Щербакова и др., 2005, 2013, 2015; Anwar et al, 2016].

Полученные $\mathrm{B}_{\text {anc }}$ мы сравнили с данными по ивакинской свите, которая, по имеющимся представлениям, является аналогом вулканитов мальцевской свиты. В разрезе ивакинской свиты сегодня предлагается выделять два кратковременных этапа (пульса) магматической активности [Павлов и др., 2011]. Среднее значение VDM для нижней кожухтинской толщи мальцевской свиты $(1.9 \pm 0.6) \times 10^{22}$ Aм$^{2}$ хорошо согласуется с данными о напряженности магнитного поля во время первого $\mathrm{P}_{1}$ пульса формирования ивакинской свиты $(1.8 \pm 1) \times 10^{22} \mathrm{Am}^{2}$ [Щербакова и др., 2015]. Значение VDM по вулканитам власовской толщи, находящихся выше по разрезу, в средней части мальцевской свиты, почти вдвое меньше $(1.1 \pm 0.7) \times 10^{22}$ Ам² $^{2}$ Такой тренд ослабления величины магнитного поля также соответствует наблюдаемым данным по разрезам ивакинской свиты Норильского района, где для времени второго $\mathrm{P}_{2}$ пульса получены значения VDM $(0.5 \pm 0.2) \times 10^{22} \mathrm{Am}^{2}$ [Щербакова и др., 2015]. Таким образом, полученные в настоящей работе низкие значения магнитного поля подтверждают не только уже довольно значимый по объему массив данных о низкой напряженности геомагнитного поля на рубеже палеозоя - мезозоя, но и прямую корреляцию мальцевской и ивакинской свит.

Значительно более высокие значения VDM в диапазоне $(5.7-6.2) \times 10^{22} \mathrm{Am}^{2}$ для этого времени представлены в работе [Blanco et al., 2012]. Эти определения выполнены по пермо-триасовым силлам на юго-востоке Восточно-Сибирской магматической провинции в пределах Ангаро-Вилюйской седловины, вблизи трубок Айхал, Юбилейная, Сытиканская. Изотопное датирование опробованных объектов не проводилось, но, исходя из геологических данных, их возраст близок к интересующему нас рубежу в 250 млн лет. Единичные высокие значения VDM среди основного массива полученных низких VDM встречаются также в работах [Heunemann et al, 2004; Солодовников, 1994]

Д. Бланко с соавторами на основании своих результатов делают вывод, что величина поля на границе пермь-триас была близкой к его современному значению, а оценки величины древнего поля, полученные другими исследователями, считают заниженными и объясняют это искажение результатов тем, что носителями NRM в изучавшихся породах были многодоменные магнитные зерна [Blanco et al., 2012].

Действительно, в ранних работах А.С. Большакова и Г.М. Солодовникова нет отдельного обсуждения доменной структуры магнитных зерен изучаемых пород просто в силу того, что в те годы проблема влияния ДС частиц на результаты определения $\mathrm{B}_{\mathrm{anc}}$ еще не была поставлена [Большаков, Солодовников, 1976; Солодовников, 1994]. Сильной 
стороной этих исследований является то, что результаты основаны на изучении внутренней и экзоконтактовой частей магматических тел (метод обожженных контактов), т.е. показано, что и обжигающие базальты, и обожженные ими в зоне контакта породы несут намагниченность одного и того же направления и одной и той же величины. В более поздних работах [Heunemann et al., 2004; Щербакова и др., 2005, 2013, 2015; Anwar et al., 2016] описываются эксперименты по оценке ДС магнитных частиц по диаграмме Дэя, термомагнитному критерию, микроэлектронным и рентгеновским исследованиям. Эти результаты показали, что в изученных породах часто присутствует смесь магнитных частиц всех размеров, но в том высокотемпературном интервале, по которому делается оценка $\mathrm{B}_{\mathrm{anc}}$, носителями ChRM являются ОД частицы или смесь ОД и малых ПОД. Именно такие зерна являются наиболее надежными носителями информации о палеонапряженности. Этот фактор является сильным аргументом в пользу надежности получаемых определений $\mathrm{B}_{\text {anc. }}$ Результаты настоящего исследования также однозначно показывают, что в изученных базальтоидах может присутствовать смесь магнитных частиц различного размера, но в температурном fit-интервале, по которому делается оценка $\mathrm{B}_{\text {anc, }}$ носителями являются ОД частицы или смесь ОД и малых ПОД зерен.

T. Анвар с соавторами предположили, что полученные высокие значения VDM в paботе [Blanco et al., 2012] являются следствием вековых вариаций [Anwar et al, 2016]. На рис. 6а показано распределение величин VDM на границе перми-триаса для интервала времени 250-252 млн лет, полученное на основании данных, представленных в базе данных по палеонапряженности, размещённой на сайте http://wwwbrk.adm.yar.ru/palmag/database.html. Параллельно на рис. 6б показано распределение величин VDM для хрона Брюнес, где заведомо мы имеем дело с сильным дипольным полем, подверженным значительным вековым вариациям. Сравнение гистограмм для этих двух эпох показывает их неплохое подобие, но вместе с тем обращает на себя внимание существенная разница в интенсивности VDM. Если для границы пермитриас максимум распределения лежит около $3 \times 10^{22} \mathrm{Am}^{2}$, то для хрона Брюнес он расположен в районе $8 \times 10^{22} \mathrm{Am}^{2}$. Существенно, что обе гистограммы не обнаруживают вторичных максимумов (небольшой провал в середине гистограмм не выходит за рамки статистических погрешностей). При этом экстремальные значения VDM, в частности, их высокие величины, обнаруженные в работе [Blanco et al., 2012], хорошо укладываются на крылья распределений, как это имеет место на гистограмме, построенной для хрона Брюнес. Это говорит о том, что данные по палеонапряженности по границе пермь-триас, полученные на сегодня и представленные в МБД, не выходят за рамки вековых вариаций, 
но при этом геомагнитное поле по своей интенсивности в этом интервале оказывается в среднем приблизительно в два раза меньше современного.

\section{ВЫВОДЫ}

В продолжение палеомагнитных и палеотектонических исследований разрезов мальцевской свиты Кузнецкого прогиба, как части Сибирской трапповой провинции, впервые выполнены эксперименты по определению абсолютной величины магнитного поля Земли на рубеже перми - триаса. Основным методом является процедура Телье-Коэ и дополнительным - метод Вилсона.

Полученные определения палеонапряженности методом Телье-Коэ удовлетворяют современным критериям достоверности. Наблюдается согласие значений $\mathrm{B}_{\mathrm{anc}}$, полученных двумя разными методами, что также повышает их надежность. Средние по сайтам значения Вапс лежат в пределах $11.0 \pm 3.9$ мкТл. Выполненные оценки VDM $(1.8 \pm 0.6) \times$ $10^{22}$ Ам $^{2}$ свидетельствуют о значительно заниженной по сравнению с современной величине виртуального дипольного момента на границе пермь-триас, что согласуется с массивом других данных по этому периоду и свидетельствует в пользу справедливости гипотезы о периоде низкого мезозойского диполя уже с этого времени. Полученные определения $\mathrm{B}_{\mathrm{anc}}$ позволяют уточнить корреляцию мальцевской свиты Кузнецкого ареала и ивакинской свиты Норильского района Сибирской крупной изверженной провинции. Показано, что нижняя - кожухтинская - часть мальцевской свиты отвечает раннему пульсу магматизма $\mathrm{P}_{1}$ ивакинской свиты, а средняя власовская часть разреза формировалась одновременно со следующим $\mathrm{P}_{2}$ пульсом.

Авторы выражают признательность коллегам В.П. Щербакову, Е.В. Кулакову, В.Ю. Брагину, Е.В. Виноградову, Е.А. Васюковой, С.К. Грибову, В.А. Цельмовичу и Л.В. Кунгурцеву за помощь в проведении полевых и экспериментальных работ и обсуждение полученных данных.

Работа выполнена при поддержке РНФ (проект № 19-17-00091), РФФИ (проекты № № 18-05-70035, 18-05-00234), Министерства науки и высшего образования (проект № FSUS-2020-0039), госзадания ИФ3 РАН и средств субсидии, выделенной Казанскому федеральному университету для выполнения государственного задания № 671-2020-0049 в сфере научной деятельности. 


\section{СПИСОК ЛИТЕРАТУРЫ}

Большаков А.С., Солодовников Г.М., Инверсия геомагнитного поля в раннем триасе // Изв. АН СССР. Физика Земли, 1976, № 6, с. 388 - 391.

Большаков А.С., Щербакова В.В. Термомагнитный критерий определения доменной структуры ферромагнетиков // Изв. АН СССР. Физика Земли, 1979, № 2, с. 38 - 47.

Буслов М.М., Сафонова И.Ю., Федосеев Г.С., Рейчоу М., Дэвис К., Бабин Г.А. Пермотриасовый плюмовый магматизм Кузнецкого бассейна (Центральная Азия): геология, геохронология, геохимия и геодинамические следствия // Геология и геофизика, 2010, т. 51 (9), с. $1310-1328$.

Веселовский Р.В., Константинов К.М., Латышев А.В., Фетисова А.М. Палеомагнетизм субвулканических траппов севера Сибирской платформы: некоторые геологические и методические следствия // Физика Земли, 2012, № 9,10, с. 74 - 87.

Диденко А.Н. О возможной причине квазипериодических колебаний частоты геомагнитных инверсий и величины $87 \mathrm{Sr} / 86 \mathrm{Sr}$ в морских карбонатных породах в фанерозое // Геология и геофизика, 2011, т. 52 (12), с. 1945 - 1956.

Добрецов Н.Л. Глобальная геодинамическая эволюция Земли и глобальные геодинамические модели // Геология и геофизика, 2010, т. 51 (6) с. 761 - 784.

Добрецов Н.Л. Периодичность геологических процессов и глубинная геодинамика // Геология и геофизика, 1994, т. 35 (5), с. 3 - 19.

Добрецов Н.Л. Взаимодействие тектоники плит и тектоники плюмов: вероятные модели и типичные примеры // Геология и геофизика, 2020, т. 61 ( 5-6), с. 617 - 647.

Добрецов Н.Л., Метелкин Д.В., Василевский А.Н. Особенности магнитного и гравитационного полей Земли, взаимосвязанные с глобальной тектоникой // Геология и геофизика, 2021, т. 52 (1) с.

Казанский А.Ю., Метелкин Д.В., Брагин В.Ю., Кунгурцев Л.В. Палеомагнетизм пермотриасового траппового комплекса Кузнецкого прогиба (Южная Сибирь) // Геология и геофизика, 2005, т. 46 (11), с. 1107 - 1120.

Крук Н.Н., Руднев С.Н., Владимиров А.Г., Журавлев Д.3. Sm-Nd-изотопная систематика гранитоидов западной части Алтае-Саянской складчатой области // ДАН, 1999, т. 366 (3), с. $395-397$.

Кутолин В.А. Трапповая формация Кузбасса. Новосибирск: Изд-во АН СССР. 1963. 117 c.

Лавренов П.Ф., Снежко Б.А., Щигрев А.Ф., Дмитриева Н.В., Филиппова Н.Е., Носков Ю.С., Зейферт Л.Л. Государственная геологическая карта Российской Федерации м-ба 1:200 000. Лист N-45-XVI (Осиновое Плесо). Объяснительная записка. СПб. ВСЕГЕИ. 2008а.

Лавренов П.Ф., Снежко Б.А., Щигрев А.Ф., Шелеметева Н.В., Филиппова Н.Е. Государственная геологическая карта Российской Федерации м-ба 1:200 000. Лист N-45XV (Ленинск-Кузнецкий). Объяснительная записка. СПб. ВСЕГЕИ. $2008 б$.

Латышев А.В., Ульяхина П.С., Веселовский Р.В. Реконструкция движения магмы в пермотриасовых интрузиях Ангаро-тасеевской синеклизы ( Сибирская платформа) по данным анизотропии магнитной восприимчивости // Геология и геофизика, 2019, т. 60 (4) с. $472-488$.

Метелкин Д.В., Лавренчук А.В., Михальцов Н.Э. О возможности записи инверсии геомагнитного поля в долеритовых силлах Норильского района: результаты математического моделирования // Физика Земли, 2019, №6, с. 24 - 33.

Михальцов Н.Э., Казанский А.Ю., Рябов В.В., Шевко А.Я., Куприш О.В., Брагин В.Ю. Палеомагнетизм траппов северо-западной части Сибирской платформы по результатам исследований керна // Геология и геофизика, 2012, т. 53 (11). с. 1595 - 1613. 
Молостовский А.Э., Печерский Магнитохроностратиграфическая шкала фанерозоя и ее описание с помощью кумулятивной функции распределения // Физика Земли, 2007, №10, с.15 - 23.

Молостовский А.Э., Храмов А.Н. Палеомагнитная шкала фанерозоя и проблемы магниостратиграфии // 27 МГК Стратиграфия, секция С01, Доклады, т.1, М.: Наука, 1984, c. $16-23$.

Нагата Т. Магнетизм горных пород. М.: Мир, 1965, 247 с.

Наставко А.В., Бородина Е.В. Изох А.Э. Петролого-минералогические особенности вулканитов центральной части Кузбасса. // Геология и геофизика, 2012, т.53 (4), с. 435 449.

Павлов В.Э., Флуто Ф., Веселовский Р.В., Фетисова А.М., Латышев А.В. Вековые вариации геомагнитного поля и вулканические пульсы в пермо-триасовых траппах Норильской и Маймеча-Котуйской провинций // Физика Земли, 2011, № 5, с. 35 - 50.

Солодовников Г.М. Палеонапряженность геомагнитно поля в раннем триасе // Физика Земли, 1994, т. 30 (9), с. 72 - 79.

Федосеев Г.С., Сотников В.И., Рихванов Л.П. Геохимия и геохронология пермотриасовых базитов северо-западной части Алтае-Саянской складчатой области // Петрология, геохимия и минералогия, 2005, т. 46 (3), с. 289 - 302

Фетисова А.М., Веселовский Р.В., Латышев А.В., Радько В.А., Павлов В.Э. Магнитная стратиграфия пермо-триасовых траппов долины реки Котуй (Сибирская платформа) в свете новых палеомагнитных данных // Стратиграфия. Геологическая корреляция, 2014, т. 22 (4), с. 36 - 51.

Щербаков В.П., Сычева Н.К. Об изменении величины геомагнитного диполя за геологическую историю Земли // Физика земли, 2006, т. 42 (3), с. 25 - 30.

Щербакова В.В., Лубнина Н. В., В. П. Щербаков, Г. В. Жидков, В. А. Цельмович, Определение палеонапряженности на неоархейских дайках Водлозерского террейна Карельского кратона // Физика Земли, 2017, № 5, с. 101 - 120 . DOI: 10.7868/S0002333717050118.

Щербакова В.В., Жидков Г.В., Латышев А.В., Щербаков В.П. Оценка вариаций палеонапряженности по Сибирским траппам Маймеча-Котуйского и Норильского районов // Физика Земли, 2013, № 4, с. 43 - 60.

Щербакова В.В., Жидков Г.В., Щербаков В.П., Латышев А.В., Фетисова А.М. О проверке гипотезы низкого мезозойского поля на трапповых породах Сибири // Физика Земли, 2015, № 3, с. 47 - 67.

Щербакова В.В., Щербаков В.П., Водовозов В.Ю., Сычева Н.К. Палеонапряженность на границе пермь- триас и в поздней перми // Физика Земли, 2005, № 11, с. 79 - 94 .

Anwar T., Hawkins L., Kravchinsky V.A., Biggin A.J., Pavlov V.E. Microwave paleointensities indicate a low paleomagnetic dipole moment at the Permo-Triassic boundary // Phys. Earth Planet. Inter, 2016, v. 260, p. 62 - 73.

Blanco D., Kravchinsky V.A., Valet J.P., Ali A., Potter D.K. Does the Permo-Triassic geomagnetic dipole low exist? // Phys. Earth Planet. Inter., 2012, v. 204, p. 11 - 21.

Coe R.S. The determination of paleointensities of the Earth's magnetic field with special emphasize on mechanisms which could cause nonideal behavior in Thellier's method // J.Geomagn. Geoelec., 1967, v. 19 (3), p. 157 - 178.

Coe R.S., Gromme C.S., Mankinen, E.A. Geomagnetic paleointensities from radiocarbon-dated lava flows on Hawaii and the question of the Pacific nondipole low // J. Geophys. Res. v. 083, 1978, p. 1740-1756.

Day R., Fuller M., Schmidt V.A. Hysteresis properties of titanomagnetites: Grain-size and compositional dependence // Phys. Earth Planet. Inter., 1977, v. 13 (4), p. 260 - 267. 
Dunlop D.J. Theory and application of the Day plot (Mrs/Ms versus Hcr/Hc) // 1.Theoretical curves and tests using titanomagnetite data // J. Geophys. Res. 107, 2002, EPM 41 - EPM 4-22.

Dunlop D.J., Özdemir Ö. Rock Magnetism: Fundamentals and Frontiers // Cambridge Univ. Press, Cambridge. 1997, p. 573.

Fabian K. Approach to saturation analysis of hysteresis measurements in rock magnetism and evidence for stress dominated magnetic anisotropy in young mid-ocean ridge basalt // Phys. Earth Planet. Inter., 2006, v. 154, p. 299 - 307.

Fabian K., Shcherbakov V.P., McEnroe S.A. Measuring the Curie temperature // Geochemistry, Geophysics, Geosystems, 2013, v. $14 \quad$ (4), p. 947 - 961, doi:10.1029/2012gc004440.

Goguitchaichvili A., Urrutia-Fucugauchi J., Alva-Valdivia L. Mesozoic Dipole Low: Myth or reality? // Eos, Transactions American Geophysical Union, 2002, v 83 (41), p. 457 468.

Gradstein F.M., Ogg J.G., Schmitz M.D., Ogg G.M. Geological Time Scale. Elsevier. 2020. 1390 p. ISBN: 9780128243602

Gurevitch E.L., Heunemann C., Rad'ko V., Westphal M., Bachtadse V., Pozzi J.P., Feinberg H. Palaeomagnetism and magnetostratigraphy of the Permian-Triassic northwest central Siberian Trap Basalts // Tectonophysics, 2004, v. 379, p. 211 - 226.

Gurevitch E.L., Westphal M., Daragan-Suchov J., Feinberg H., Pozzi J.P., Khramov A.N. Paleomagnetism and magnetostratigraphy of the traps from Western Taimyr (Northern Siberia) and the Permo-Triassic crisis // Earth Planet. Sci. Lett, 1995, v. 136, p. 461 - 473.

Heunemann C., Krasa D., Soffel H., Gurevitch E., Bachtadse V. Directions and intensities of the Earth's magnetic field during a reversal: results from the Permo-Triassic Siberian trap basalts, Russia // Earth and Planetary Science Letters, 2004, v. 218, p. 197 - 213.

Hongfu Y., Kexin Z., Jinnan T., Zunyi Y., Shunbao W. The Global Stratotype Section and Point (GSSP) of the Permian-Triassic boundary // Episodes, 2001, № 2, p. 102 - 114.

Kravchinsky V.A., Konstantinov K.M., Courtillot V., Savrasov J.I., Valet J.P., Cherniy S.D., Mishenin S.G., Parasotka S. Palaeomagnetism of the east Siberian traps and kimberlites: two new poles and palaeogeographic reconstruction at about 360 and 250 Ma. // Geophys. J. Int., 2002, v. 148, p. $1-33$.

Laj, C., Kissel C., Beer J., High Resolution Global Paleointensity Stack since 75 kyr (GLOPIS-75) calibrated to absolute values // Timescales of the Internal Geomagnetic Field, v. 145, p. $255-265$.

Larson R.L., Olson P. Mantle plumes control magnetic reversal frequency // Earth and Planetary Science Letters, 1991, v.107, p. 437 - 447.

Latyshev A.V., Veselovskiy R.V., Ivanov A.V. Paleomagnetism of the Permian-Triassic intrusions from the Tunguska syncline and the Angara-Taseeva depression, Siberian Traps Large Igneous Province: evidence of contrasting styles of magmatism // Tectonophysics, 2018, v. 723, p. 41 - 55, doi:10.1016/j.tecto.2017.11.035.

Leonhardt R., Hufenbecher F., Heider F., Soffel H.C. High absolute paleointensity during a mid Miocene excursion of the Earth’s magnetic field // Earth Planet. Sci. Lett., 2000, v. 184(1), p. $141-154$.

Lind E., Kropotov S., Czamanske G., Gromme S., Fedorenko V. Paleomagnetism of the Siberian Flood Basalts of the Noril'sk Area: A Constraint on Eruption Duration // International Geology Review, 1994, v. 36 (12), p. 1139 - 1150.

Maxworthy A.R. Revisiting a domain-state independent method of palaeointensity determination // Phys. Earth Planet. Inter., 2010, v. 179, p. 21 - 31.

Nishitani T., Kono M. Curie temperature and lattice constant of oxidized titanomagnetite // Geophys. J. R. Astron. Soc., 1983. v. 74, p. 585 - 600.

Olson P., Amit H. Mantle superplumes induce geomagnetic superchrons. // Front. Earth Sci. 2015, 3:38, doi: 10.3389/feart.2015.00038 
Pavlov V.E., Courtillot V., Bazhenov M.L., Veselovsky R.V. Paleomagnetism of the Siberian traps: New data and a new overall 250 Ma pole for Siberia // Tectonophysics, 2007, № 443, p. $72-92$.

Prevot M., Derder M.E.-M., McWilliams M., Thompson J. Intensity of the Earth's magnetic field: Evidence for a Mesozoic dipole low // Earth Planet. Sci. Lett. 1990, v. 97 (1,2), p. 129 - 139. doi: 10.1016/0012-821x(90)90104-6.

Prevot M., Mankinen E.A., Coe, R.S., Gromme C.S., The Steens Mountain (Oregon) geomagnetic polarity transition 2. Field intensity variations and discussion of reversal models // J. Geophys. Res., 1985, v. 90(B12), p. 10417 - 10448.

Reichow M.K., Pringle M.S., Al’Mukhamedov A.I., Allen M.B., Andreichev V.L., Buslov M.M., Davies C.E., Fedoseev G.S., Fitton J.G., Inger S., Medvedev A.Ya., Mitchell C., Puchkov V.N., Safonova I. Yu., Scott R.A., Saunders A.D. The timing and extent of the eruption of the Siberian Traps large igneous province: Implications for the end-Permian environmental crisis // Earth Planet. Sci. Lett., 2009, v. 277, p. 9 - 20.

Reichow M.K., Saunders A.D., Millar I.L., Puchkov V.N., Safonova I.Yu., Buslov M.M., Scott R.A., Medvedev A.Ya., Al'Mukhamedov A.I. Characterising the world's most catastrophic volcanism: constraints from trace elements and radiogenic isotopes of the Siberian Traps large igneous province // Geophys. Res., Abstracts, 2010, v. 12, EGU2010-12475-1.

Selkin P., Tauxe L. Long-term variations in paleointensity // Philosophical Transactions of the Royal Society London, 2000, v. 358, p. $1065-1088$.

Shaar R., Tauxe L. Thellier GUI: An integrated tool for analyzing paleointensity data from Thellier-type experiments // Geochem. Geophys. Geosyst., 2013, v. 14 (3), p. 677 - 692.

Shcherbakova V.V., Bakhmutov V.G., Thallner D., Shcherbakov V.P., Zhidkov G.V., Biggin A.J. Ultra-low palaeointensities from East European Craton, Ukraine support a globally anomalous palaeomagnetic field in the Ediacaran // J. Geophys. Res., 2020, v. 220, p. 1928 1946.

Shcherbakova V.V., Shcherbakov V.P., Heider F. Properties of partial thermoremanent magnetization in pseudosingle domain and multidomain magnetite grains // J. Geophys. Res., 2000, v. 105 (B1), p. $767-781$.

Steiner M.B. The magnetic polarity time scale across the Permian-Triassic boundary // Non-marine Permian biostratigraphy and biochronology // Geol. Soc., London, Special Publications, 2006, v. 265, p. 15 - 38.

Tarduno J.A., Cottrell R.D., Smirnov A.V. High geomagnetic intensity during the midCretaceous from Thellier analyses of single plagioclase crystals // Science, 2001, v. 291 (5509), p. 1779 - 1783. doi: 10.1126/science.1057519.

Tarduno J.A., Cottrell R.D., Smirnov A.V. The paleomagnetism of single silicate crystals: Recording geomagnetic field strength during mixed polarity intervals, superchrons, and inner core growth // Rev. Geophys, 2006, v. 44 (1), RG1002. Doi: 10.1029/2005RG000189.

Thellier E., Thellier O. Sur l'intensité du champ magnétique terrestre dans le passé historique et géologique // Ann. De Geophys., 1959, v. 15, p. 285 - 376.

Wilson, R.L. The thermal demagnetization of natural magnetic moments in rocks // Geophys. J. Int., 1961, v. 5, p. $45-58$. 
Рис. 1. Схема распространения продуктов пермско-триасового базальтоидного магматизма Сибирской крупной изверженной провинции (а) и геологическая схема территории Кузнецкого ареала (б) по [Буслов и др., 2010] с дополнениями.

1 - нижнемеловые-палеогеновые отложения; 2, 3 - юрская угленосная моласса: 2 нижне-среднеюрская, 3 - нижнеюрская; 4, 5 - позднепермско?-среднетриасовые комплексы: 4 - нерасчлененные туфогенно-осадочные и магматические, 5 - туфогенноосадочные; 6 - пермская угленосная моласса; 7 - нижне-верхнекарбоновые угленосные отложения; 8 - палеозойские осадочно-метаморфогенные и магматические образования (кембрий-ранний карбон); 9 - силлы салтымаковского комплекса, 10 - силлы и дайки сыркашевского комплекса; 11 - надвиги; 12 - другие разломы, преимущественно, сдвиги.

Рис. 2. Схема геологического строения района исследований по [Казанский и др., 2005]

1 - четвертичные аллювиальные отложения; 2 - юрская угленосная моласса: а нижнеюрская, б - нижнесреднеюрская; 3 - верхнепермско-среднетриасовые туфогенноосадочные образования; 4 - нерасчлененные раннесреднетриасовые магматические и туфогенно-осадочные образования; 5 - пермская угленосная моласса; 6 раннедевонские вулканогенно-осадочные образования; 7 - раннеордовикские вулканогенно-осадочные образования; 8 - раннепалеозойский аккреционный комплекс; 9 - позднепермско?-раннетриасовые силлы; 10 - преимущественно сдвиги; 11 - точки отбора образцов; 12 -имеющиеся значения абсолютного возраста в млн лет по [Reichow et al., 2009].

Рис. 3. Иллюстрация магнитных свойств и результатов экспериментов Телье и Вилсона для каждого изучаемого сайта (подписи образцов на рисунке): (а) - линии намагниченности насыщения $\mathrm{M}_{\mathrm{si}}(\mathrm{T})$; (б) - кривые магнитной восприимчивости к(T) (штриховая линия - нагрев и охлаждение до $360^{\circ} \mathrm{C}$, сплошная линия - то же до $600^{\circ} \mathrm{C}$ ); (в) - диаграммы Араи-Нагата; (г) - соответствующие диаграммы Зийдервельда (в координатах образца); (д) - термомагнитные кривые NRM, TRM и TRM* (штриховая линия) (к методу Вилсона).

Рис. 4. Иллюстрация оценки доменного состояния образцов: (а) - петля гистерезиса образца кожухтинской толщи (штриховая линия - индуктивная намагничниченность $\mathrm{M}_{\mathrm{i}}$ ); (б) - участок с измеренной индуктивной намагниченностью (штриховая линия) в области 400-700мТ, аппроксимированный двумя функциями: линейной $\mathrm{M}_{\mathrm{i}}(\mathrm{B})=\mathrm{aB}+\mathrm{M}_{\mathrm{s}}$ (светлосерая линия) и с учетом недонасыщения $\mathrm{M}_{\mathrm{i}}(\mathrm{B})=\mathrm{aB}+\mathrm{M}_{\mathrm{s}}-\mathrm{b} / \mathrm{B}$ (темно-серая); (в) - разница квадратов линий аппроксимации от измеренной кривой; (г) - эксперимент по выявлению «хвоста» pTRM в температурном интервале (250, $\mathrm{T}_{0}$ ) для образца кожухтинской толщи; (д) - диаграмма Дэя-Данлопа, красная и черная линии - экспериментальная и теоретическая кривые перехода от ОД к МД состоянию для магнетита с условным содержанием МД компоненты в процентах [Dunlop, 2002], синими линиями отделены области доменного состояния.

1 -измеренная кривая; 2 - линейная аппроксимация; 3 - линейная аппроксимация с учетом недонасыщения; 4 - кожухтинская толща; 5 - власовская толща. 
Рис. 5. Микроснимки образцов кожухтинской толщи: шлиф представительного образца Ad52 в крупном масштабе (а) и увеличенные в 10 раз детальные фрагменты того же шлифа (б, в), фотография магнитной вытяжки для образца Ad49 с подписанными размерами зерен титаномагнетита (г). Pl - плагиоклаз, Cpl - клинопероксен, Ti-Mgt титаномагнетит.

Рис. 6. Гистограммы VDM для интервала времени 250-252 млн лет (а) и хрона Брюнес (б), построенные по МБД. Левая гистограмма построена по данным работ [Щербакова и др., 2005, 2013, 2015; Солодовников, 1994; Heunemann, 2004; Blanco, 2012] с включением результата, полученного в настоящей работе. Сплошная кривая линия представляет нормальное распределение, аппроксимирующее диаграммы. 
Таблица 1. Результаты экспериментов по определению палеонапряженности.

\begin{tabular}{|c|c|c|c|c|c|c|c|c|c|c|c|c|c|c|}
\hline Sample & $\mathbf{B}_{\text {lab }}$ & $\mathbf{T}_{1}-\mathbf{T}_{2}$ & Np & GAP & $\mathbf{Q}$ & $\mathbf{F}$ & $\mathbf{B}_{\mathrm{anc}}$ & beta & FRAC & $\mathrm{d}(\mathbf{C K})$ & DRAT & CDRAT & B $_{\text {anc }} *$ & $\mathbf{T}_{1}-\mathbf{T}_{2}$ \\
\hline \multicolumn{15}{|c|}{$\begin{array}{l}\text { Кожухтинская толща: } \\
\text { исток руч. Бугас ad-1 }\end{array}$} \\
\hline Ad05 & 50 & $100-275$ & 7 & 0.820 & 9.3 & 0.750 & 15.0 & 0.066 & 0.692 & 0.96 & 1.22 & -0.62 & \multirow{4}{*}{8.2} & \multirow{4}{*}{$50-277$} \\
\hline Ad05вибро & 10 & $100-300$ & 9 & 0.870 & 12.8 & 0.923 & 8.5 & 0.063 & 0.836 & 4.95 & 4.09 & 3.26 & & \\
\hline Ad08 & 50 & $100-275$ & 7 & 0.809 & 8.5 & 0.750 & 13.1 & 0.071 & 0.706 & 0.93 & 1.20 & -0.07 & & \\
\hline Ad09 & 50 & $100-275$ & 7 & 0.816 & 8.6 & 0.769 & 15.2 & 0.073 & 0.734 & 0.61 & 0.75 & 0.77 & & \\
\hline Ad10вибро & 20 & 200-300 & 5 & 0.643 & 5.2 & 0.319 & 11.9 & 0.039 & 0.458 & 4.34 & 11.71 & 7.03 & \multirow[t]{3}{*}{8.8} & \multirow[t]{3}{*}{$200-350$} \\
\hline Ad11 & 50 & $100-275$ & 7 & 0.817 & 10.3 & 0.779 & 15.9 & 0.062 & 0.768 & 0.78 & 0.96 & 1.45 & & \\
\hline Ad12 & 50 & $100-275$ & 7 & 0.822 & 9.3 & 0.766 & 14.0 & 0.068 & 0.718 & 2.00 & 2.52 & -1.91 & & \\
\hline Ad13_дубль & 50 & 100-275 & 6 & 0.783 & 8.2 & 0.769 & 16.5 & 0.074 & 0.698 & 4.07 & 5.03 & 6.94 & \multirow{3}{*}{9.8} & \multirow{3}{*}{$75-292$} \\
\hline Ad13 & 50 & $100-275$ & 7 & 0.814 & 11.5 & 0.738 & 13.8 & 0.052 & 0.700 & 2.90 & 3.79 & 5.97 & & \\
\hline Ad14 & 50 & $100-275$ & 7 & 0.817 & 5.3 & 0.780 & 11.1 & 0.120 & 0.632 & 2.34 & 2.93 & 2.23 & & \\
\hline \multicolumn{13}{|c|}{ устье руч. Бугас ad-2 } & \multirow{9}{*}{40.5} & \multirow{9}{*}{$115-299$} \\
\hline Ad15 & 50 & $125-275$ & 7 & 0.833 & 12.6 & 0.751 & 11.4 & 0.050 & 0.717 & 3.24 & 4.21 & 7.20 & & \\
\hline Ad16 & 50 & $125-275$ & 7 & 0.831 & 19.2 & 0.711 & 11.5 & 0.031 & 0.657 & 0.60 & 0.83 & 0.99 & & \\
\hline Ad17_дубль & 55 & $125-300$ & 8 & 0.852 & 18.7 & 0.807 & 11.9 & 0.037 & 0.800 & 6.00 & 7.27 & 6.23 & & \\
\hline Ad17 & 50 & $125-300$ & 8 & 0.847 & 11.4 & 0.791 & 10.5 & 0.059 & 0.748 & 2.37 & 2.94 & 5.37 & & \\
\hline Ad19 & 50 & $100-275$ & 8 & 0.842 & 10.3 & 0.760 & 10.5 & 0.062 & 0.642 & 3.51 & 4.52 & 9.02 & & \\
\hline Ad19-дубль & 50 & $100-275$ & 8 & 0.850 & 64.7 & 0.817 & 10.4 & 0.011 & 0.405 & 2.96 & 3.55 & 5.42 & & \\
\hline Ad20 & 50 & $125-300$ & 8 & 0.834 & 9.5 & 0.737 & 10.5 & 0.065 & 0.662 & 5.18 & 6.88 & 9.04 & & \\
\hline Ad21 & 50 & $100-300$ & 8 & 0.826 & 13.2 & 0.816 & 13.6 & 0.051 & 0.807 & 4.07 & 4.81 & 5.70 & & \\
\hline \multicolumn{13}{|c|}{ устье руч. Кожухта ad-5 } & \multirow{13}{*}{13.7} & \multirow{13}{*}{$100-450$} \\
\hline Ad43 & 50 & $125-300$ & 8 & 0.842 & 7.7 & 0.755 & 9.7 & 0.082 & 0.595 & 2.72 & 3.54 & -0.19 & & \\
\hline Ad44 & 50 & $125-300$ & 8 & 0.852 & 11.6 & 0.825 & 14.5 & 0.060 & 0.823 & 1.78 & 2.07 & -1.35 & & \\
\hline Аd45вибро & 10 & $300-500$ & 9 & 0.773 & 9.7 & 0.885 & 15.1 & 0.070 & 0.805 & 7.2 & 4.50 & -12.85 & & \\
\hline Ad46 & 50 & $175-275$ & 5 & 0.731 & 8.3 & 0.741 & 12.9 & 0.065 & 0.667 & 8.02 & 10.48 & 12.55 & & \\
\hline Ad47 & 50 & $175-300$ & 6 & 0.759 & 10.9 & 0.762 & 16.3 & 0.053 & 0.730 & 4.75 & 5.93 & 4.64 & & \\
\hline Ad48 & 50 & $125-300$ & 8 & 0.846 & 11.9 & 0.736 & 10.3 & 0.052 & 0.608 & 4.56 & 6.06 & -3.40 & & \\
\hline Ad49 & 50 & $125-300$ & 8 & 0.846 & 13.9 & 0.752 & 12.3 & 0.046 & 0.792 & 1.99 & 2.57 & -1.55 & & \\
\hline Аd49вибро & 10 & $100-280$ & 10 & 0.879 & 32.0 & 0.752 & 9.0 & 0.021 & 0.701 & 1.83 & 1.81 & 1.06 & & \\
\hline Ad49вибро2 & 10 & $100-300$ & 9 & 0.870 & 27.0 & 0.865 & 10.3 & 0.028 & 0.831 & 2.89 & 2.33 & 1.82 & & \\
\hline Ad50 & 50 & $125-300$ & 8 & 0.848 & 14.2 & 0.792 & 9.8 & 0.047 & 0.730 & 2.60 & 3.22 & 2.60 & & \\
\hline Ad51 & 50 & $125-300$ & 8 & 0.846 & 11.7 & 0.722 & 13.3 & 0.052 & 0.725 & 3.21 & 4.29 & -3.03 & & \\
\hline Ad52вибро & 10 & $100-280$ & 10 & 0.882 & 46.4 & 0.750 & 9.4 & 0.014 & 0.690 & 1.97 & 1.91 & 4.33 & & \\
\hline
\end{tabular}




\begin{tabular}{|c|c|c|c|c|c|c|c|c|c|c|c|c|c|c|}
\hline Ad52 & 50 & $100-300$ & 9 & 0.866 & 17.2 & 0.822 & 14.2 & 0.041 & 0.780 & 4.13 & 4.83 & 2.30 & & \\
\hline Ad53 & 50 & $125-275$ & 7 & 0.799 & 9.2 & 0.950 & 14.0 & 0.083 & 0.778 & 5.77 & 5.85 & 3.73 & & \\
\hline Ad54вибро & 10 & $100-375$ & 12 & 0.723 & 22.2 & 0.900 & 19.2 & 0.029 & 0.893 & 2.59 & 1.33 & -0.49 & 16.4 & $100-350$ \\
\hline Ad55вибро & 10 & $100-275$ & 8 & 0.848 & 9.8 & 0.896 & 7.2 & 0.077 & 0.528 & 2.14 & 1.94 & -2.71 & 5.2 & $100-275$ \\
\hline \multicolumn{15}{|c|}{ Власовская толща, устье руч. Дулепова ad-3 } \\
\hline Ad23 & 50 & $150-325$ & 8 & 0.814 & 3.9 & 0.362 & 12.7 & 0.077 & 0.393 & 4.65 & 12.45 & -13.97 & \multirow{10}{*}{6.1} & \multirow{10}{*}{$250-400$} \\
\hline Ad23вибро & 10 & $100-250$ & 8 & 0.779 & 6.3 & 0.712 & 5.0 & 0.089 & 0.592 & 2.35 & 2.95 & 2.94 & & \\
\hline Ad25 & 50 & $225-360$ & 9 & 0.823 & 6.2 & 0.628 & 3.1 & 0.083 & 0.183 & 7.78 & 12.36 & -4.2 & & \\
\hline Ad26 & 50 & $225-350$ & 7 & 0.832 & 10.3 & 0.577 & 3.1 & 0.047 & 0.168 & 6.51 & 11.27 & 1.65 & & \\
\hline Ad26вибро & 10 & $100-265$ & 10 & 0.806 & 9.2 & 0.789 & 4.2 & 0.069 & 0.401 & 2.52 & 2.94 & 0.92 & & \\
\hline Ad27 & 50 & $125-350$ & 10 & 0.847 & 17.2 & 0.759 & 6.7 & 0.037 & 0.681 & 3.90 & 5.10 & 9.64 & & \\
\hline Ad28вибро & 10 & 235-315 & 7 & 0.712 & 8.2 & 0.605 & 7.2 & 0.053 & 0.637 & 3.12 & 4.19 & 4.26 & & \\
\hline Ad29вибро & 10 & $100-210$ & 6 & 0.689 & 4.0 & 0.672 & 3.9 & 0.117 & 0.439 & 3.67 & 5.08 & 6.06 & & \\
\hline Ad31 & 50 & $150-250$ & 5 & 0.711 & 5.5 & 0.764 & 2.3 & 0.099 & 0.296 & 6.06 & 7.92 & 11.14 & & \\
\hline Ad32 & 50 & $150-275$ & 6 & 0.660 & 4.2 & 0.528 & 11.9 & 0.083 & 0.241 & 3.37 & 6.22 & 11.53 & & \\
\hline Ad32вибро & 15 & $150-325$ & 10 & 0.783 & 18.7 & 0.877 & 11.7 & 0.037 & 0.747 & 11.01 & 9.92 & 11.75 & 14.1 & $150-275$ \\
\hline
\end{tabular}

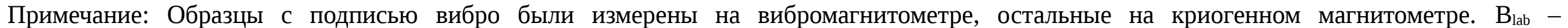

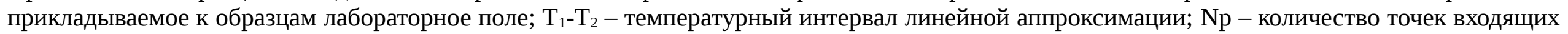

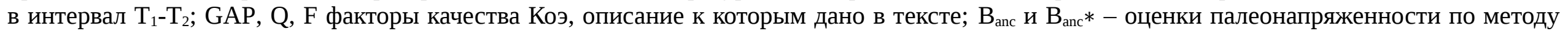
Телье-Коэ и Вилсона. 
Таблица 2. Средние значения палеонаправлений и палеоинтенсивности исследуемой коллекции.

\begin{tabular}{|c|c|c|c|c|c|c|c|c|c|c|c|c|c|}
\hline \multirow{2}{*}{$\begin{array}{l}\text { Сай } \\
\text { T }\end{array}$} & \multicolumn{5}{|c|}{ Палеонаправления } & \multicolumn{5}{|c|}{ Палеоинтенсивность } & \multicolumn{3}{|c|}{ VDM (mean for site) $\times 10^{22} \mathrm{Am}^{2}$} \\
\hline & $\mathrm{Nd}$ & Dec $^{\circ}$ & Inco & $\mathrm{k}$ & $\alpha 95^{\circ}$ & $\mathrm{N} / \mathrm{n}$ & $\mathrm{B}_{\mathrm{anc}} \mu \mathrm{T}$ & $\mathrm{B}_{\mathrm{anc}}$ St.err. $\mu \mathrm{T}$ & $\mathrm{B}_{\mathrm{anc}}$ St.err. \% & $\mathrm{B}_{\mathrm{anc}}$ St.dev. $\mu \mathrm{T}$ & VDM & $\begin{array}{l}\text { VDM } \\
\text { St.err }\end{array}$ & $\begin{array}{l}\text { VDM } \\
\text { St.dev }\end{array}$ \\
\hline $\begin{array}{l}\text { Кожу } \\
\text { истон }\end{array}$ & $\begin{array}{l}\text { гин } \\
\text { учч. }\end{array}$ & $\begin{array}{l}\text { я толщ } \\
\text { гас }\end{array}$ & & & & & & & & & & & \\
\hline $\begin{array}{c}\text { ad-1 } \\
\text { устье }\end{array}$ & $\begin{array}{l}13 \\
\text { уч. }\end{array}$ & $\begin{array}{l}212.7 \\
\text { гас }\end{array}$ & -67 & 354.5 & 2.2 & $10 / 14$ & 13.5 & 0.73 & 5.4 & 2.3 & 2.19 & 0.12 & 0.37 \\
\hline $\begin{array}{l}\text { ad-2 } \\
\text { устье }\end{array}$ & $\begin{array}{r}7 \\
\text { уч. }\end{array}$ & $\begin{array}{r}213.2 \\
\text { жухта }\end{array}$ & -68.4 & 620.9 & 2.4 & $8 / 8$ & 11.3 & 0.36 & 3.2 & 1.0 & 1.83 & 0.06 & 0.16 \\
\hline ad-5 & 12 & 233.5 & -65.3 & 163 & 3.4 & $16 / 19$ & 12.4 & 0.8 & 6.3 & 3.1 & 2.01 & 0.11 & 0.51 \\
\hline $\begin{array}{c}\text { Влас } \\
\text { устье } \\
\text { ad-3 }\end{array}$ & $\begin{array}{r}\text { ска } \\
\text { уч. } \\
11\end{array}$ & $\begin{array}{c}\text { олща } \\
\text { ллепова } \\
248\end{array}$ & -63.5 & 173.4 & 3.6 & $11 / 19$ & 6.5 & 1.2 & 17.9 & 3.9 & 1.05 & 0.20 & 0.65 \\
\hline
\end{tabular}

Примечание: $\mathrm{Nd}$ - количество образцов в сайте; Dес - склонение; Inc - наклонение; k - кучность; $\alpha_{95}-95 \%$ овал доверия; n/N - количество использованных в статистике к общему количеству изученных образцов; St.err - стандартная ошибка; St.dev - cтандартное отклонение. 


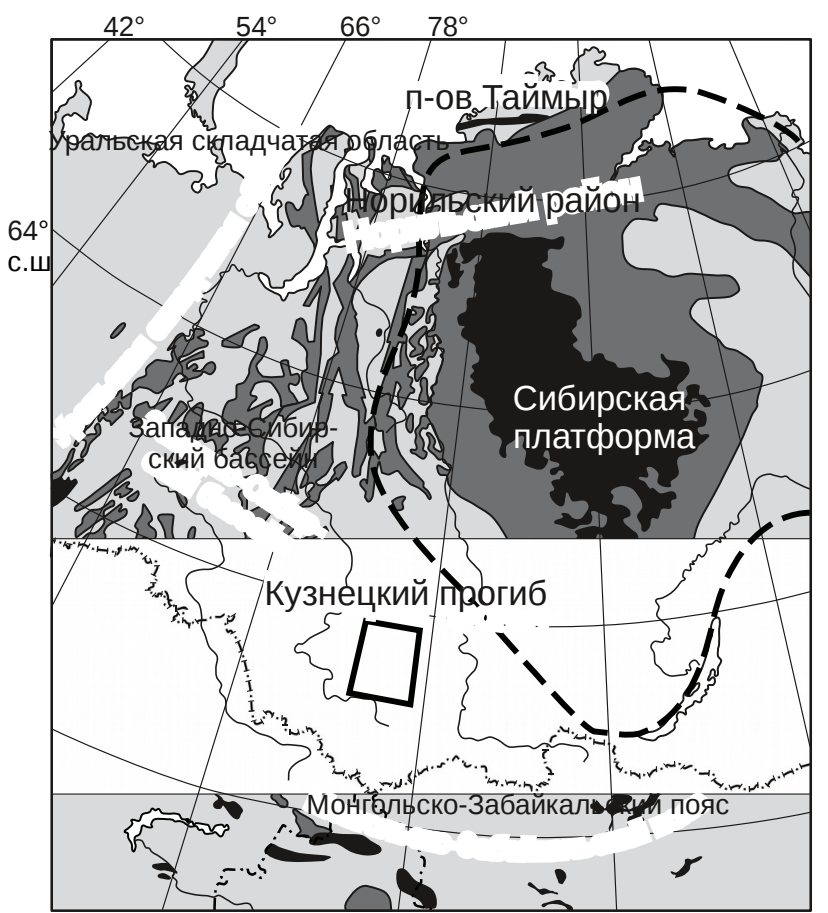

Базиты выходящие на поверхность

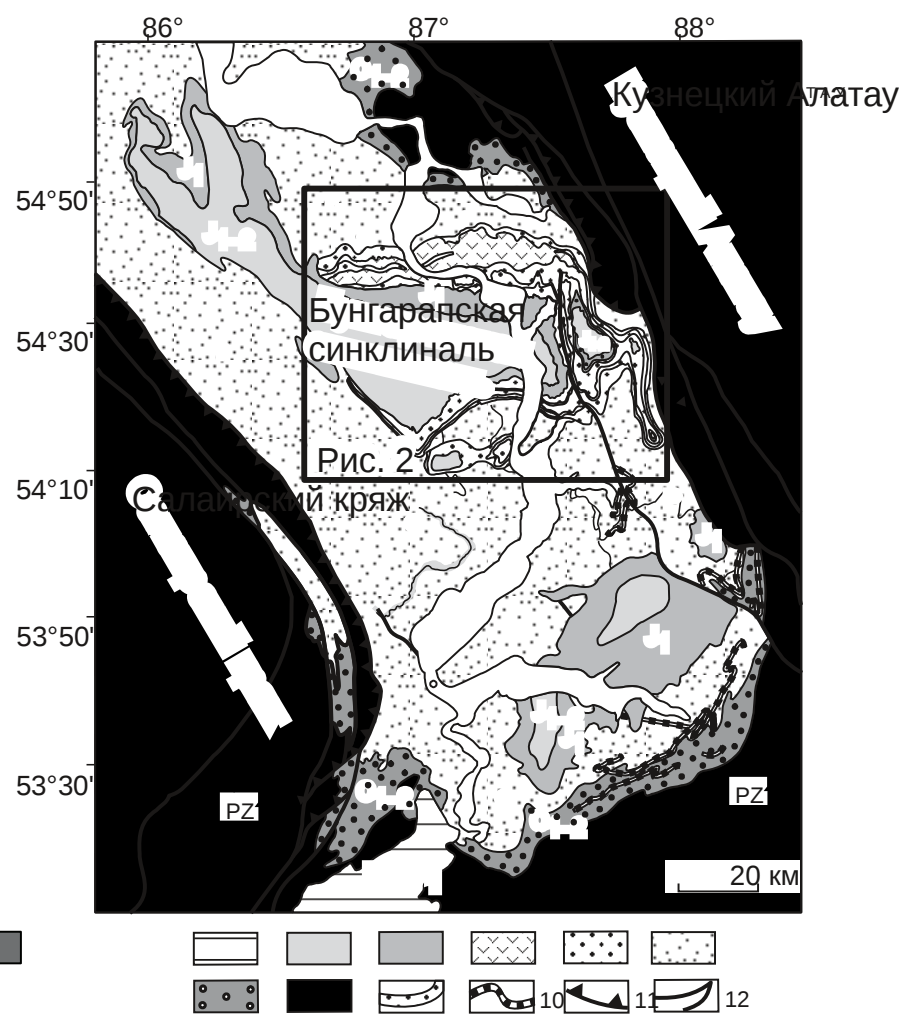




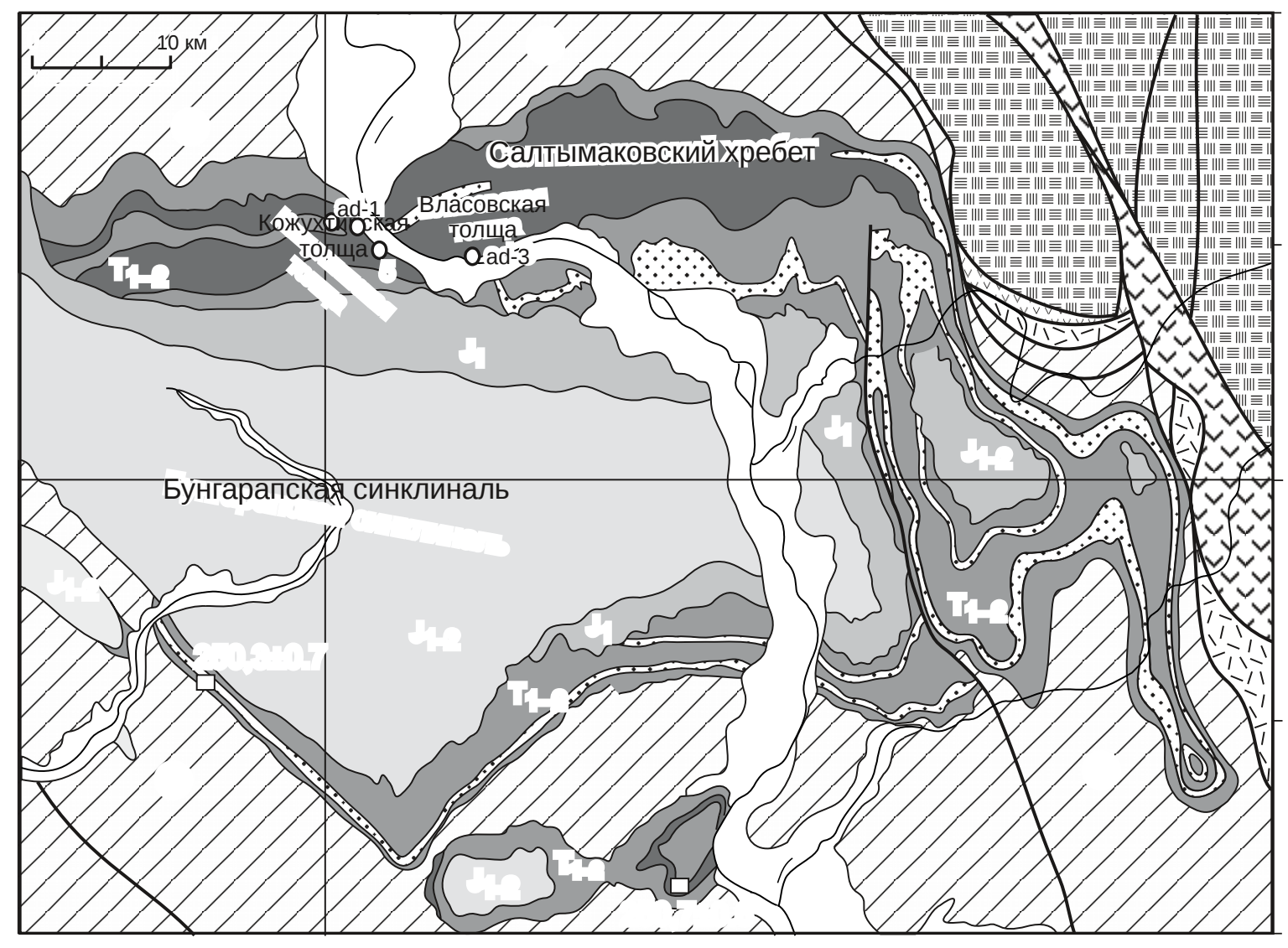

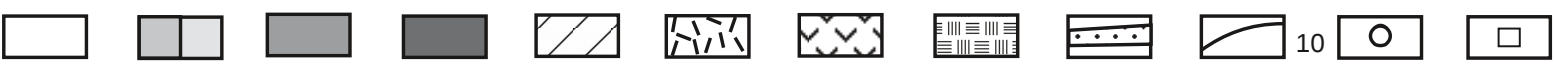




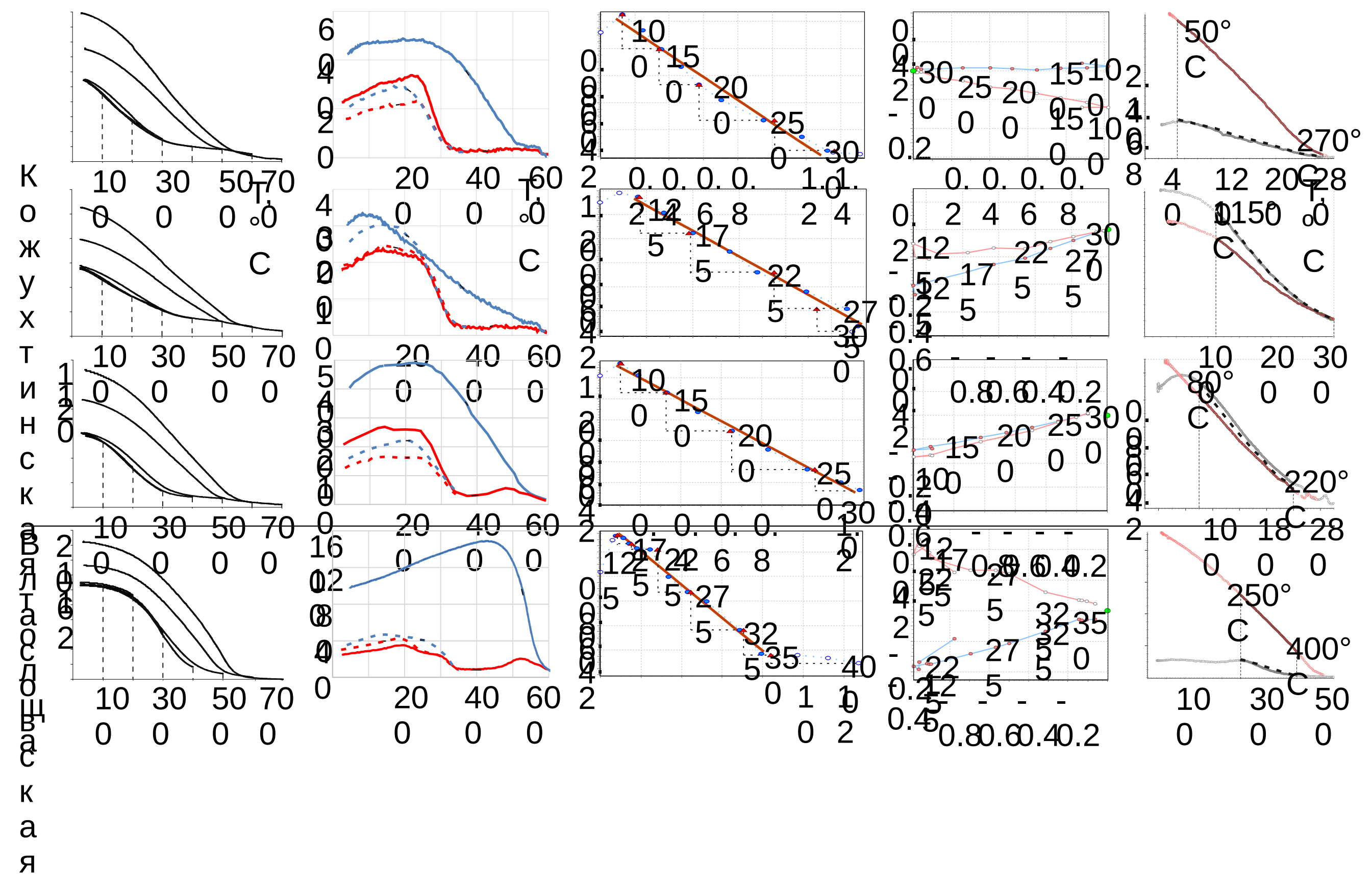


a)

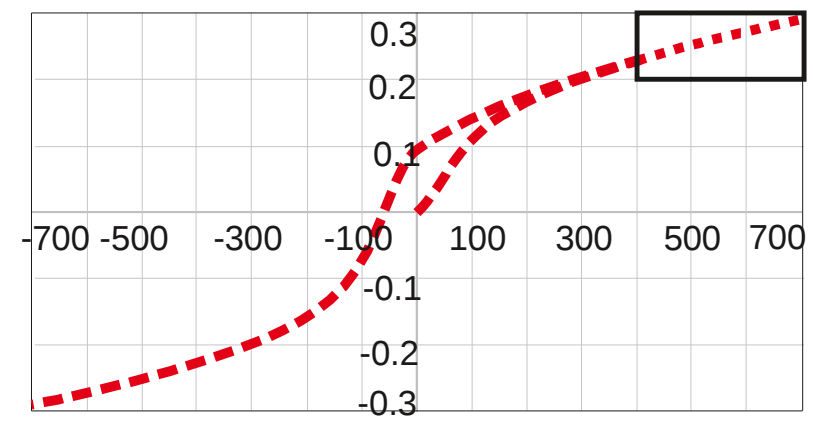

B)

д)

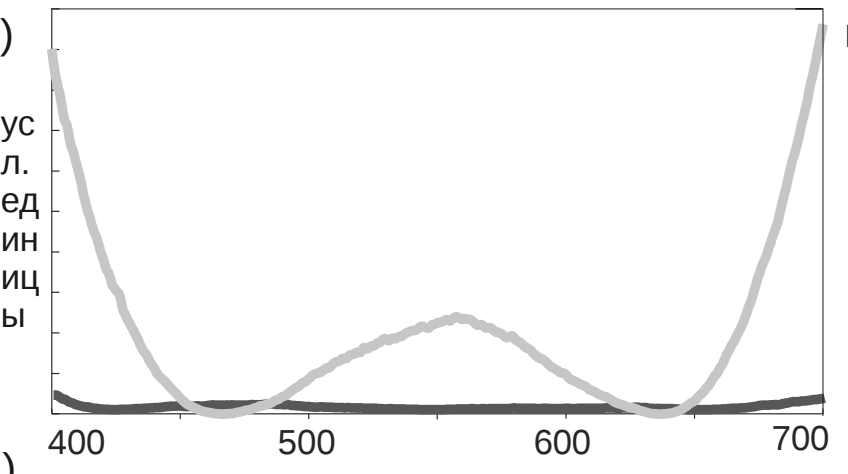

б) 0.3

0.28

0.26

0.24

0.22

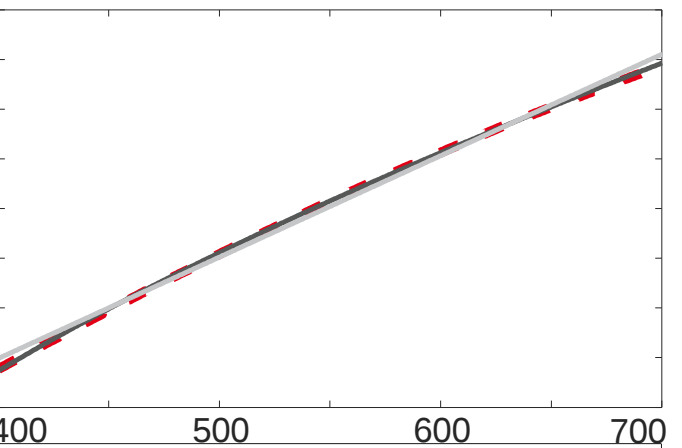

г)
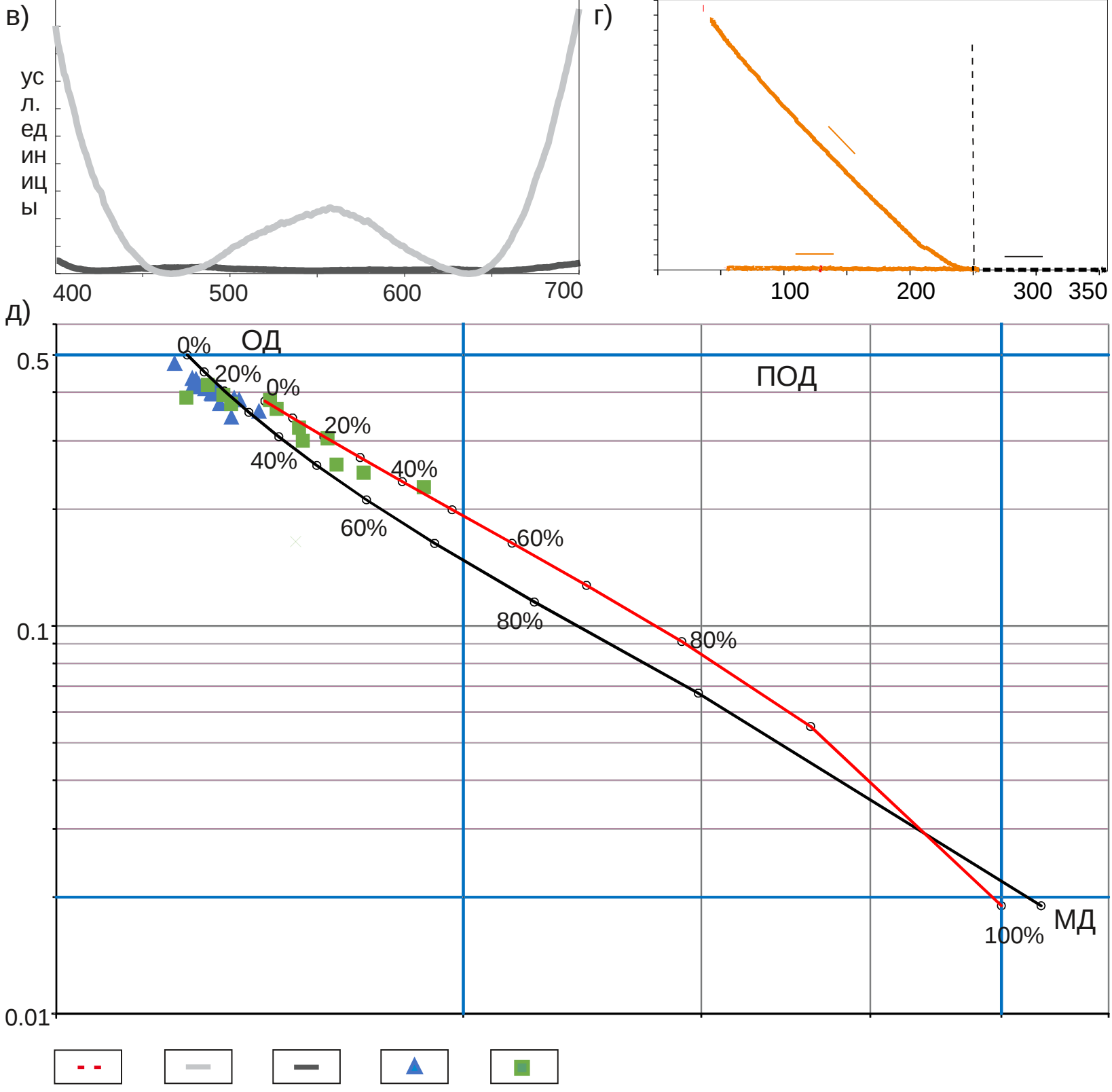
(a)

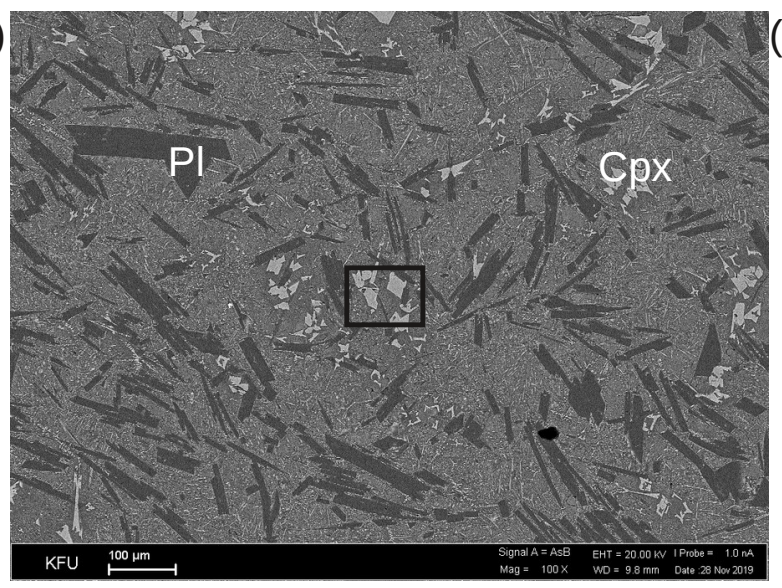

(B)

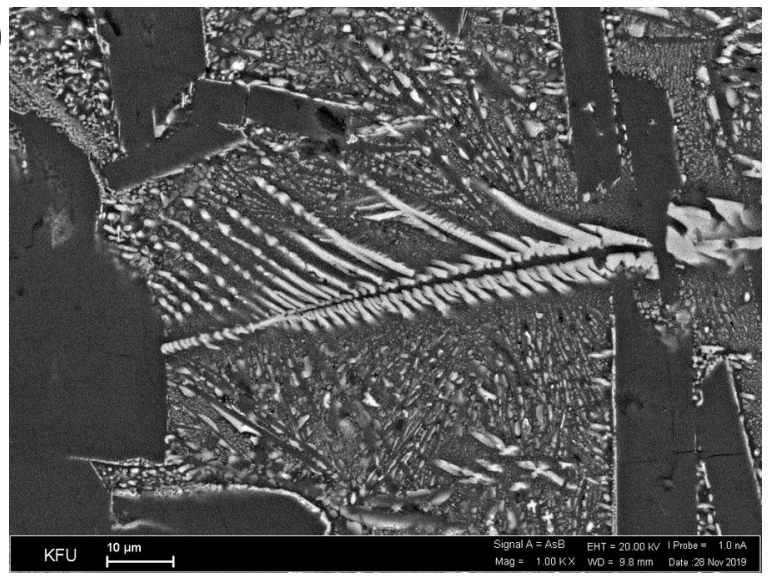

(б)

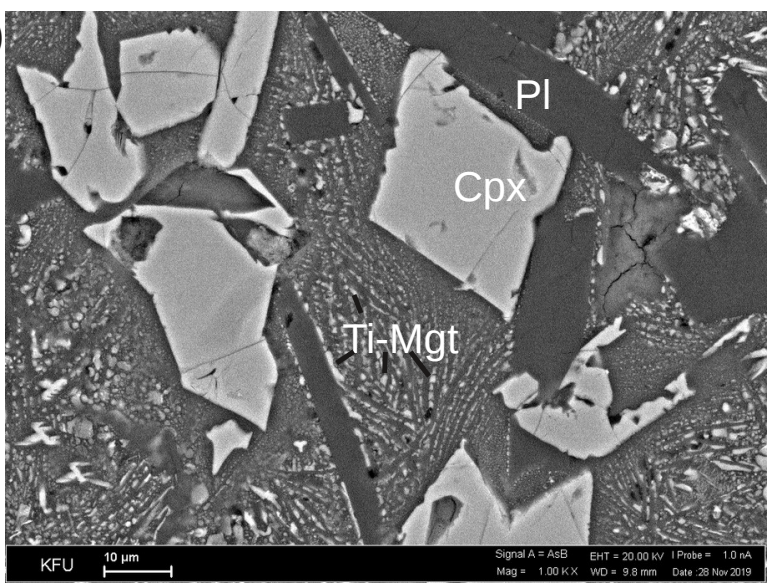

(r)

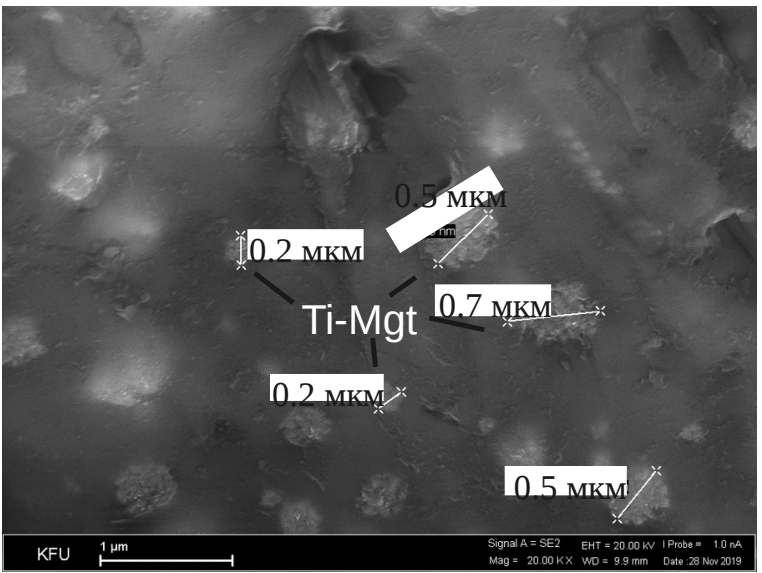




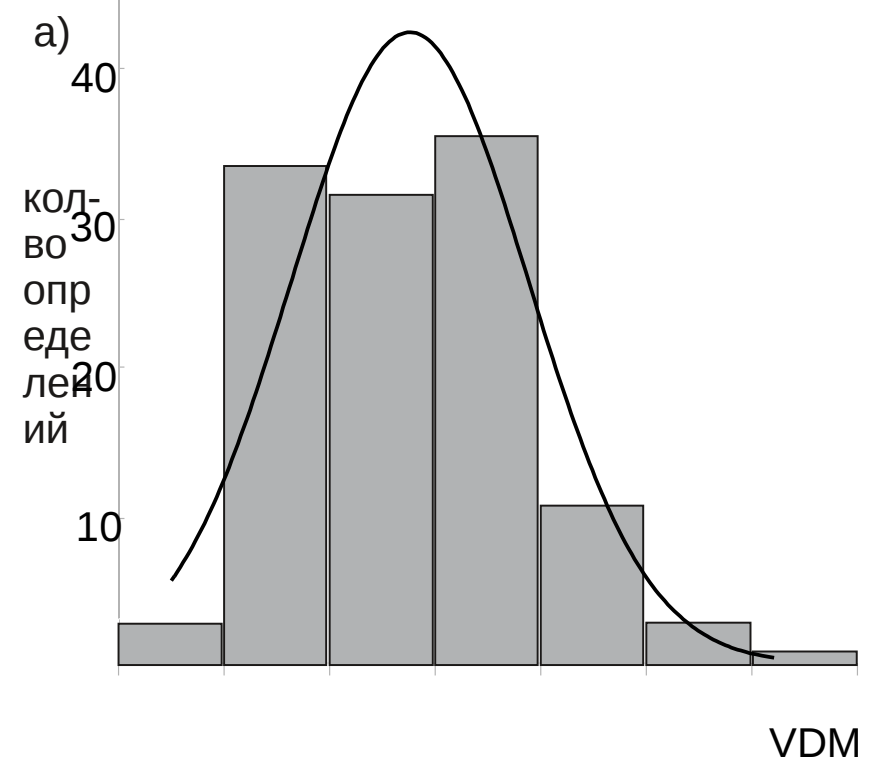

б)

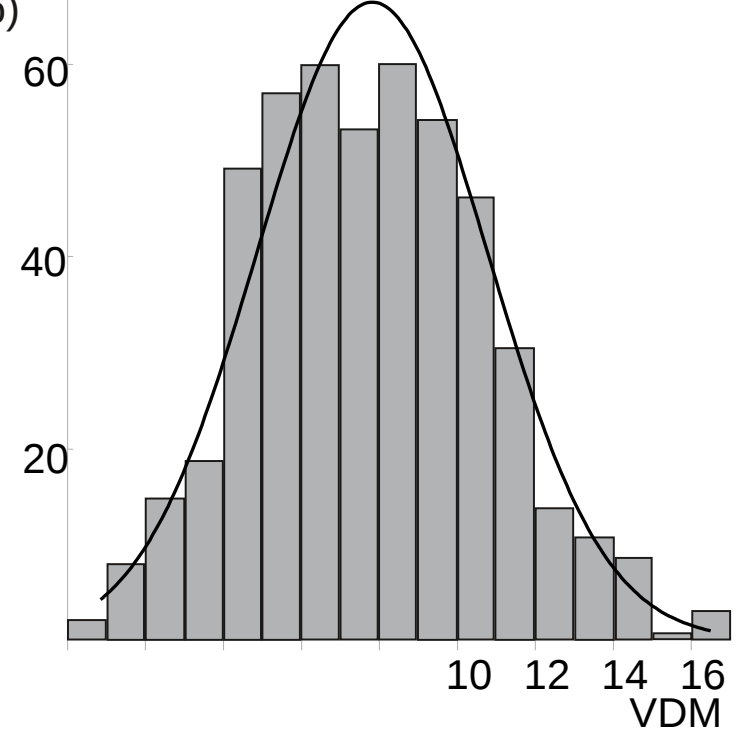

